\title{
Pengaruh Kecerdasan Emosi dan Konsep Diri Terhadap Kemampuan Mengajar Guru Taman Kanak-Kanak
}

\author{
Nila Fitria ${ }^{1}$ \\ ${ }^{1}$ Program Studi Pendidikan AUD, Fakultas Psikologi dan Pendidikan, Universitas Al Azhar \\ Indonesia, Jalan Sisingamangaraja, Kompleks Masjid Agung al Azhar, Kebayoran Baru, Jakarta \\ Selatan, 12110
}

Penulis untuk Korespondensi/E-mail: nilafitria@uai.ac.id

\begin{abstract}
Abstrak - Penelitian ini bertujuan untuk mengetahui tentang hubungan antara kedua variabel bebas (kecerdasan emosi dan konsep diri) dengan variabel terikat (kemampuan mengajar guru taman kanak-kanak). Populasi dalam penelitian ini adalah adalah seluruh guru Taman KanakKanak se-Kecamatan Larangan Tangerang (jumlah guru sebanyak 310 orang). Hasil penelitian ini menyimpulkan bahwa: (1) Terdapat hubungan yang signifikan antara kecerdasan emosi $\left(X_{1}\right)$ dengan kemampuan mengajar guru taman kanak-kanak $(Y)$, koefisien korelasi antara kecerdasan emosi $\left(\mathrm{X}_{1}\right)$ dengan kemampuan mengajar guru taman kanak-kanak sebesar 0,32 . Melalui uji-t diperoleh $t_{\text {hit }}$ sebesar 2,48 lebih besar dari pada $t_{\text {tab }}$ sebesar 1,67 sehingga koefisien korelasi $\left(\mathbf{r}_{\mathrm{y} 1}\right)$ dinyatakan signifikan. (2) Terdapat hubungan yang signifikan antara konsep diri $\left(\mathrm{X}_{2}\right)$ dengan kemampuan mengajar guru taman kanak-kanak, koefisien korelasi antara konsep diri $\mathrm{X}_{2}$ dengan kemampuan mengajar guru taman kanak-kanak (Y) sebesar 0,48. Melalui uji-t diperoleh $t_{\text {hit }}$ sebesar 3,98 lebih besar dari pada $t_{\text {tab }}$ sebesar 1,67 sehingga koefisien korelasi $\left(r_{y 2}\right)$ dinyatakan signifikan. (3) Koefisien korelasi ganda secara bersama-sama antara kecerdasan emosi dan konsep diri dengan kemampuan mengajar guru taman kanak-kanak diperoleh $\left(\mathbf{R}_{\mathbf{y} 12}\right)$ sebesar 0,48. Pengujian signifikansi melalui uji $F$ diperoleh $F_{\text {hit }}$ sebesar $\mathbf{8 , 0 0}$ lebih besar dari pada $F_{\text {tab }}$ sebesar 3,18 sehingga koefisien korelasi ganda $\left(R_{y 12}\right)$ dinyatakan signifikan berarti bahwa semakin tinggi kecerdasan emosi dan konsep diri secara bersama-sama semakin tinggi juga kemampuan mengajar guru taman kanak-kanak. Sebaliknya, semakin rendah kecerdasan emosi dan konsep diri semakin rendah juga kemampuan mengajar guru taman kanak-kanak.
\end{abstract}

Kata Kunci - Kecerdasan Emosi, Konsep Diri, Kemampuan Mengajar Guru TK

Abstract - This study aims to find out about the relationship between the two independent variables(emotional intelligence and self-concept) with the dependent variable(the ability of teachers to teach kindergarten).The population in this study is the entire kindergarten teacher as Tangerang District Larangan(the number of teachers as much as310 people).The results of this study concluded that: (1) There is a significant relationship between emotional intelligence(X1) with the ability to teach a kindergarten teacher(Y), the coefficient of correlation between emotional intelligence(X1) with the ability to teach a kindergarten teacher $(Y)$ at 0,32 . Through the t-test of 2.48 obtained $t$-calculate is greater than-table correlation coefficient f1.67 (ry1) expressed significant. ( 2 )There is a significant relationship between self-concept (X2) with the ability of teachers to teach kindergarten, the correlation coefficient between self-concept X2 with the ability to teach a kindergarten teacher(Y) at 0,48 . Through the $t$-test of 3.98 obtained Thit is greater than that-table correlation coefficient of 1.67(ry2) expressed significant. (3)The coefficient of multiple correlation jointly between emotional intelligence and self-concept and ability to teach a kindergarten teacher was obtained (Ry12) of 0.48 . Testing the significance of F-calculate obtained through the F-test of 8.00 greater than 3.18 so F-table for multiple correlation coefficient $(\mathbf{R y} 12)$ revealed a significant means that the higher the emotional intelligence and self-concept together the higher the ability of teachers to teach kindergarten as children.Conversely, the lower the self-concept of emotional intelligence and the lower the ability of teachers to teach kindergarten.

Keyword - Emotional Intelligence, Self Concept, Teaching Skills Kindergarten Teachers 


\section{PENDAHULUAN}

\section{Latar Belakang}

Untuk mewujudkan tujuan pembangunan nasional dibidang pendidikan yaitu mencerdaskan kehidupan bangsa dan meningkatkan kualitas sumber daya manusia yang beriman, bertakwa dan berakhlak mulia serta menguasai ilmu pengetahuan dan teknologi serta seni diperlukan pendidikan berkualitas seperti yang tercantum dalam Undang-Undang Republik Indonesia No 20 tahun 2003 tentang Pendidikan Nasional (UU Sisdiknas), yang mengemukakan bahwa pendidikan nasional bertujuan mengembangkan potensi peserta didik agar menjadi manusia yang beriman dan bertaqwa kepada Tuhan Yang Maha Esa, berakhlak mulia, sehat, berilmu, cakap, kreatif, mandiri dan menjadi warga negara yang demokratis serta bertanggung jawab dalam rangka mencerdaskan kehidupan bangsa.

Di dalam UU No. 14, pasal 7 ayat 1 menyebutkan UU ini mengatur tentang sikap profesionalisme guru. Dalam melihat permasalahan pendidikan anak usia dini pasti tidak terlepas dari kualitas guru yang mengajar. Guru yang profesional harus memenuhi standar kompetensi yang telah ditetapkan oleh undangundang dan pemerintah dengan memenuhi empat Kompetensi Pendidik PAUD. Di dalam UU No. 20 Pasal 40 ayat 2 menyebutkan Kewajiban pendidik adalah

a. Menciptakan suasana pendidikan yang bermakna, menyenangkan , kreatif, dinamis dan dialogis

b. Mempunyai komitmen secara profesional untuk meningkatkan mutu pendidikan

c. Memberi teladan dan menjaga nama baik lembaga, profesi dan kedudukan sesuai dengan kepercayaan yang diberikan kepadanya

Guru sebagai pendidik memiliki peran yang sangat penting dan strategis dalam mencapai keberhasilan pembelajaran. Guru adalah pendidik yang menjadi tokoh panutan dan identifikasi bagi peserta didik dan lingkungannya, oleh karena itu guru harus memiliki standar kualitas pribadi tertentu yang mencakup tanggungjawab, wibawa, mandiri, dan disiplin. ${ }^{1}$

Berdasarkan pengalaman penulis sebagai guru, ujian berat bagi guru dalam hal kepribadian adalah rangsangan yang memancing emosinya. Kestabilan emosi amat diperlukan, namun tidak semua orang mampu menahan emosi terhadap ransangan yang menyinggung perasaan. Kematangan emosi guru akan berkembang sejalan dengan pengalaman kerja selama guru mau memanfaatkan $\mathrm{p}$

engalamannya. Jadi tidak sekedar jumlah umur atau masa kerja yang bertambah, melainkan bertambahnya kemampuan memecahkan masalah atas dasar pengalaman masa lalu.

Intinya seorang guru harus memiliki Kemampuan Mengajar yang berkualitas dan memiliki kecerdasan emosional yang stabil dalam menghadapi karakteristik lingkungan kerjanya yang multi problem sehingga terciptanya konsep diri yang positif.

Berdasarkan uraian yang telah dipaparkan diatas, maka penelitian ini ditujukan untuk menguji dan meneliti kemampuan mengajar guru TK.

\section{Pembatasan Masalah}

Berdasarkan latar belakang dan identifikasi masalah tersebut di atas, serta permasalahan yang harus diteliti sangat luas, maka penelitian ini dibatasi dalam tiga variabel, yaitu:

1. Kecerdasan emosi sebagai variabel bebas $\left(\mathrm{X}_{1}\right)$

2. Konsep diri sebagai variabel bebas $\left(\mathrm{X}_{2}\right)$

3. Kemampuan mengajar guru TK sebagai variabel terikat $(\mathrm{Y})$

\section{Perumusan Masalah}

Adapun rumusan masalah dalam penelitian ini adalah sebagai berikut:

1. Apakah terdapat pengaruh kecerdasan emosi terhadap kemampuan mengajar guru TK?

2. Apakah terdapat pengaruh konsep diri terhadap kemampuan mengajar guru TK?

3. Apakah terdapat pengaruh kecerdasan emosi dan konsep diri terhadap kemampuan mengajar guru TK ?

\footnotetext{
${ }^{1}$ Mulyasa. 2007. Menjadi Guru Profesional.

Bandung : PT. Remaja Rosdakarya, h. 37
} 


\section{TINJAUAN PUSTAKA}

\section{Kecerdasan Emosi}

\section{Pengertian Kecerdasan Emosi .}

Setelah mengetahui apa itu kecerdasan (inteligensi) dan apa itu emosi, selanjutnya akan dibahas tentang Emotional Intelligence (EI) atau kecerdasan emosional. Kecerdasan emosional merupakan kemampuan seperti kemampuan untuk memotivasi diri sendiri dan bertahan menghadapi frustasi; mengendalikan dorongan hati dan tidak melebih-lebihkan kesenangan; mengatur suasana hati dan menjaga agar bebas stress tidak melumpukan kemampuan berpikir; berempati dan berdoa ${ }^{2}$.

Menurut Saphiro, istilah kecerdasan emosi pertama kali dilontarkan pada tahun 1990 oleh dua orang ahli, yaitu Peter Salovey dan John Mayer untuk menerangkan jenis-jenis kualitas emosi yang dianggap penting untuk mencapai keberhasilan. Jenis-jenis kualitas yang dimaksudkan antara lain: (1) empati, (2) mengungkapkan dan memahami perasaan, (3) mengendalikan amarah, (4) kemampuan kemandirian, (5) kemampuan menyesuaikan diri, (6) diskusi, (7) kemampuan memecahkan masalah antarpribadi, (8) ketekunan, (9) kesetiakawanan, (10) keramahan, dan (11) sikap hormat ${ }^{3}$.

Teori lain dikemukakan oleh Reuvan Bar-On, sebagaimana dikutip oleh Steven J. Stein dan Howard E. Book, ia menjelaskan bahwa kecerdasan emosional adalah serangkaian kemampuan, kompetensi, dan kecakapan nonkognitif yang memengaruhi kemampuan seseorang untuk berhasil mengatasi tuntutan dan tekanan lingkungan. Selanjutnya, Steven J. Stein dan Howard E. Book menjelaskan pendapat Peter Salovey dan John Mayer, pencipta istilah kecerdasan emosional, bahwa kecerdasan emosional adalah kemampuan untuk mengenali perasaan, meraih dan membangkitkan perasaan untuk membantu pikiran, memahami perasaan dan maknanya, mengendalikan perasaan secara mendalam

${ }^{2}$ Daniel Goleman, Emotional Intelligence,

Kecerdasan Emosional, Jakarta: Gramedia Pustaka Utama, 1997, hlm. 45

${ }^{3}$ Lawrence E. Saphiro, How To Raise A Child with A High EQ: A Present Guide to Emotional

Intelligence, Jakarta: Gramedia, 1997, hlm. 9-10 sehingga membantu perkembangan emosi dan intelektual ${ }^{4}$.

Semakin tinggi kecerdasan emosional kita, semakin besar kemungkinan untuk sukses sebagai pekerja, orang tua, manajer, anak dewasa bagi orang tua kita, mitra bagi pasangan hidup kita, atau calon untuk suatu posisi jabatan 5 .

Mengutip pendapat Davies, Monty P. Satia Darma mengatakan bahwa kecerdasan emosi adalah kemampuan seseorang untuk mengendalikan emosi dirinya sendiri dan orang lain, membedakan satu emosi dengan lainnya dan menggunakan informasi tersebut untuk menuntut proses berfikir serta perilaku seseorang. ${ }^{6}$

Menurut Veithzal, kemampuan untuk mengendalikan emosi merupakan basis kemampuan watak, dengan memiliki sifat kasih sayang kepada sesama yang terletak pada empati yaitu kemampuan membaca perasaan orang lain. ${ }^{?}$

Berdasarkan uraian di atas dapat disimpulkan bahwa kecerdasan emosional merupakan kecakapan yang dimiliki seseorang dalam hal pengendalian diri, pengelolaan stress, berempati dan membina hubungan antar sesama.

\section{Konsep Diri}

Self concept berawal dari pengertian self itu sendiri. Istilah self dalam psikologi mempunyai dua arti yaitu: self sebagai objek adalah sikap dan perasaan seseorang terhadap dirinya sendiri dan self sebagai proses adalah suatu keseluruhan proses psikologis yang menguasai tingkah laku dan penyesuaian diri. Self sebagai objek menunjukkan sikap, perasaan, pengamatan, dan penelitian seseorang terhadap dirinya. Self sebagai proses adalah suatu kesatuan yang terdiri dari proses-proses aktif seperti berpikir, mengingat, dan mengamati.

\footnotetext{
${ }^{4}$ Steven. J. Stein and Howard E.Book, The IQ Edge : Emotional Intelligence and Your Succes, Bandng: Kaifa, 2002, hlm. 30

${ }^{5}$ Steven.J.Stein dan Howard.E.Book, op.cit,.hlm. 23 ${ }^{6}$ Monty P. Satia Darma. 2003. Mendidik

Kecerdasan. Jakarta : Pustaka Populer Obor,h.27. ${ }^{7}$ Veithzal Rivai, 2003. Kiat Memimpin Dalam Abad ke -21, Jakarta, PT Raja Grafindo Persada, h. 15
} 
Self dalam artian ini sering disebut sebagai ego. ${ }^{8}$

Symond menyatakan self sebagai cara-cara bagaimana seseorang bereaksi terhadap dirinya sendiri. Self mengandung empat aspek yaitu':

a) Bagaimana orang mengamati dirinya ada

b) Bagaimana orang berpikir tentang dirinya sendiri

c) Bagaimana orang menilai dirinya sendiri

d) Bagaimana orang berusaha dengan berbagai cara untuk menyempurnakan dan mempertahankan diri.

Brooks mendefinisikan konsep diri sebagai "those physical, social, and psychological perceptions of ourselves that we have derived from experiences and our interaction with others" ${ }^{\prime \prime}$. Konsep diri adalah pandangan dan perasaan kita terhadap diri kita. Persepsi tentang diri ini bersifat fisik, sosial, dan psikologis. Taylor et mendefinisikan konsep diri sebagai "all you think and feel about you. The entire complex of beliefs and attitudes you hold about your self' 11 . Jadi konsep diri merupakan penilaian tentang diri kita yang meliputi apa yang dipikirkan dan apa yang dirasakan oleh diri kita.

Konsep diri adalah semua ide, pikiran, kepercayaan dan pendirian yang diketahui individu tentang dirinya dan mempengaruhi individu dalam berhubungan dengan orang lain. Hal ini temasuk persepsi individu akan sifat dan kemampuan, interaksi dengan orang lain dan lingkungan, nilai-nilai yang berkaitan dengan pengalaman dan objek, tujuan serta keinginannya ${ }^{12}$. Konsep diri merupakan cara individu memandang dirinya. Konsep diri merupakan suatu ukuran kualitas yang memungkinkan seseorang dianggap dan dikenali sebagai individu yang berbeda dengan individu lainnya.

Konsep diri merupakan sistem operasi yang menjalankan komputer mental, yang mempengaruhi kemampuan berpikir seseorang.

\footnotetext{
${ }^{8}$ Sumadi Suryabrata, Psikologi Pendidikan, (Jakarta

:CV Rajawali, 1995) h. 35

${ }^{9}$ Ibid.hlm. 40

${ }^{10}$ Artikel Psikologi, http//www.google.com

${ }^{11}$ ibid h. 63

${ }^{12}$ Modul Pelatihan Resolusi Konflik,

http//www.google.com
}

Konsep diri setelah terinstall akan masuk di pikiran bawah sadar dan mempunyai bobot pengaruh sebesar $88 \%$ terhadap tingkat kesadaran seseorang dalam suatu saat. Semakin baik konsep diri, maka akan semakin mudah seseorang untuk berhasil ${ }^{13}$

\section{Kemampuan Mengajar Guru Taman Kanak-Kanak}

\section{Pengertian Kemampuan (Ability)}

Menurut Robbins "ability (kemampuan, kecakapan, ketangkasan, bakat, kesanggupan) merupakan tenaga (daya kekuatan) untuk melakukan suatu perbuatan". Kemampuan bisa merupakan kesanggupan bawaan sejak lahir, atau merupakan hasil latihan atau praktek"14.

Kemampuan menurut Robbin: merujuk ke suatu Kompetensi seseorang untuk mengerjakan berbagai tugas dalam suatu pekerjaan tertentu. Menurut Usman, kemampuan merupakan gambaran hakikat kualitatif dari perilaku yang rasional untuk mencapai tujuan yang diprasyaratkan dengan kondisi yang diharapkan. 15 Rustiyah mengemukakan bahwa kompetensi mengandung pengertian pemilikan pengetahuan, keterampilan dan kemampuan yang ditentukan oleh jabatan tertentu. Lebih lanjut kompetensi merupakan kemampuan untuk mencapai hasil secara mudah mengkordinasikan perilaku yang relative efektif utnuk suatu tujuan yang jelas. ${ }^{16}$ Beyer (2000:1) menyatakan bahwa kompetensi dapat diperlihatkan seseorang dengan cara atas bentuk kemampuannya dalam menyelesaikan tugas yang berhubungan dengan materi tertentu. Jadi kemampuan merupakan daya atau kekuatan yang dimiliki oleh seseorang dalam bertindak.

\section{Pengertian Guru}

James M. Cooper: "A teacher is person charged with the responsibility of helpingothers to learn and to behave in new different

\footnotetext{
${ }^{13}$ Wuryanano, http//www.google.com

${ }^{14}$ Robbins. Stephen. P , Perilaku Organisasi, Edisi

Bahasa Indonesia, Jilid I.Jakarta: PT.

Prenlindo, 1996

${ }^{15}$ Usman, Moh. Uzer. Menjadi Guru

Profesional.Bandung: Remaja Rosdakarya. 1996

${ }^{16}$ M.K. Rustiyah, Kompetensi Mengajar dan Guru,

( Jakarta : Masco, 1979), cet. I, h. 17
} 
ways".Itulah sebabnya guru adalah pekerjaan professional yang membutuhkankemampuan khusus hasil proses pendidikan yang dilaksanakan oleh lembaga pendidikan keguruan. Hal ini seperti diungkapkan Greta G.

Morine-Dershimer: "A professional is a person who possesses some specialized knowledge and skill, can weigh alternatives and select from among a number of potentially productive actions one that is particulary appreciate in a given situation". Untuk meyakinkan bahwa guru sebagai pekerjaan professional, marilah kita tinjau syarat-syarat atau ciri pokok dari pekerjaan professional.

1) Pekerjaan professional ditunjang oleh suatu ilmu tertentu secara mendalam yang hanya mungkin diperoleh dari lembagalembaga pendidikan yang sesuai, sehingga kinerjanya didasarkan kepada keilmuan yang dimilikinya yang dapat dipertanggungjawabkan secara ilmiah.

2) Suatu profesi menekankan kepada suatu keahlian dalam bidang tertentu yang spesifik sesuai dengan jenis profesinya, sehingga antara profesi yang satu dengan yang lainnya dapat dipisahkan secara tegas.

3) Tingkat kemampuan dan keahlian suatu profesi didasarkan kepada latar belakang pendidikan yang dialaminya yang diakui oleh masyarakat, sehingga semakin tinggi latar belakang pendidikan akademik sesuai dengan profesinya, semakin tinggi pula tingkat keahliannya, dengan demikian semakin tinggi pula tingkat penghargaan yang diterimanya.

4) Suatu profesi selain dibutuhkan oleh masyarakat juga memiliki dampat sosial kemasyarakatan, sehingga masyarakat memiliki kepekaan yang sangat tinggi terhadap setiap efek yang ditimbulkannya dari pekerjaan profesinya itu.

Menurut Muhibbin Syah, guru adalah: "tenaga pendidik yang pekerjaan utamanya adalah mengajar, kegiatan mengajar yang dilakukan guru tidak hanya beroriantasi pada kecakapankecakapan berdimensi ranah cipta saja tetapi kecakapan yang berdimensi ranah rasa dan karsa"17.

\footnotetext{
${ }^{17}$ Muhibbin Syah. Psikologi Pendidikan. Bandung: PT Remaja Rosdakarya.1999 h. 223
}

Menurut Nana Syaodih bahwa:"guru mempunyai peranan ganda sebagai pengajar dan pendidik. Kedua peran tersebut bisa dilihat perbedaannya, tetapi tidak bisa dipisahkan.Tugas utama sebagai pendidik adalah membantu mendewasakan anak didik, dewasa secara psikologis, sosial dan moral. Dewasa secara psikologis berarti individu telah mampu berdiri sendiri, tidak tergantung pada orang lain, juga telah mampu bertanggung jawab atas segala perbuatannya, mampu bersikap objektif"18.

Seseorang profesional adalah orang yang memiliki beberapa pengetahuan dan keahlian khusus, dapat menetukan alternatif dan memilih dari beberapa aksi-aksi produktif yang berpotensi yang sesuai dengan situasi yang terjadi. Jadi guru adalah prrofesi yang prosesional dalam mentransfer pengetahaun, keterampilan, dan keahlian khusus lainnya sesuai situasi dan kondisi.

\section{Kemampuan Mengajar}

Berkaitan dengan kemampuan mengajar merupakan kegiatan intensional atau yang disengaja dan kegiatan yang bersifat normative. Kemampuan ini dititik beratkan kepada tugas guru dalam mengajar. Kegiatan belajar mengajar terdiri dari tiga komponen utama, yaitu:

1) Pengajar yang mengajar

2) Peserta didik yang diajar

3) Bahan ajar yang diberikan oleh pengajar Ketiga komponen tersebut saling berkaitan dalam mencapai tujuan pengajaran. Diantara ketiga komponen tersebut guru memegang peranan yang penting sebagai tenaga pengajar.

Mengajar merupakan tugas yang sangat kompleks. Menjadi seorang guru yang berhasil memerlukan sifat-sifat: memiliki kualitas pribadi, mempunyai sikap positif terhadap ilmu pengetahuan yang akan diajarkan, meguasai dasar-dasar pengetahuan tentang belajar dan mengajar, menguasai pengetahuan tentang perkembangan manusia dan cara belajar, menguasai pengajaran dan pengelolaan kelas, menguasai sejumlah keterampilan mengajar, memiliki sikap dan keterampilan mengajar, memiliki sikap dan keterampilan yang

\footnotetext{
${ }^{18}$ Nana Syaodih. . Landasan Psikologi Proses Pendidikan, Bandung: PT Remaja Rosdakarya 2003.hlm. 252
} 
mendorong siswa untuk berpikir reflektif dan mampu memecahkan masalah.

Guru harus memiliki empat kompetensi atau kemampuan, yaitu: (1) memilikipengetahuan tentang belajar dan tingkah laku siswa (2) memiliki sikap yang tepat terhadap diri sendiri, sekolah, siswa, teman sejawat dan mata pelajaran yang di bina (3)menguasai mata pelajaran yang akan diajarakan (4) memiliki keterampilan teknis dalam mengajar antara lain: merencanakan pengajaran, mengajukan pertanyaan kepada siswa, berkomunikasi dengan siswa, mengelolahkelas dan mengadakan evaluasi hasil belajar siswa.

Tiga tahapan tugas mengajar, yaitu ${ }^{19}$ :
1. Sebelum mengajar
2. Pelaksanaan Pengajaran
3. Sesudah pengajaran

Pertama, Sebelum Pengajaran, berkenaan dengan: (a) perumusan tujuan pengajaran (b) pemilihan metode (c) pemilihan pengalaman mengajar (d) pemilihan bahan pelajaran, fasilitas belajar dan peralatan (e) cara membuka, pengembangan dan menutup pengajaran (f) peranan dan pengelompokkan siswa. Kedua, Pelaksanaan pengajaran, meliputi (a) pengelolaan kelas dan pengendalian kelas (b) penyampaian informasi, keterampilan dan proses (c) penggunaan tingkah laku non verbal (d) cara mendapatkan balikan (f) prinsip-prinsip psikologi (g)diagnosis kesulitan belajar (h) evaluasi kegiatan interaksi. Ketiga, Sesudah Pengajaran berkenaan dengan : (a) penilaian pekerjaan siswa (b) perencanaan kegiatan berikutnya dan (c) penilaian kembali kegiatan belajar mengajar yang telah dilakukan.

Kemampuan merencanakan kegiatan pengajaran adalah kegiatan yang dilakukan terlebih dahulu sebelum kegiatan pengajaran dimulai. Kemampuan guru dalam merencanakan kegiatan pengajaran meliputi: memahami tujuan pengajaran, mengidentifikasikan topik-topik pelajaran dan menetapkan tujuan umum untuk semua topik, mengenali karakteistik siswa, membuat tujuan pengajaran menjadi spesifik dalam bentuk tingkah laku siswa, mengenali subjek dan isi setiap materi, mengembangkan alat ukur,

${ }^{19}$ Hasibuan dan Madjono, Jurna Pendidikan, 1998 h. 38 menyaring kegiatan belajar mengajar beserta sumber, serta mengembangkan alat evaluasi hasil belajar.

Berdasarkan uraian di atas maka dapat disimpulkan bahwa kemampuan mengajar seorang guru merupakan kompetensi yang dimiliki guru dalam mentransfer pengetahuan guna mencapai tujuan pendidikan.

\section{Hipotesis Penelitian}

Berdasarkan pemikiran di atas, maka hipotesis yang hendak diuji kebenarannya dapat dirumuskan sebagai berikut :

1. Hipotesis I

Terdapat hubungan langsung kecerdasan emosio terhadap kemampuan mengajar guru TK

2. Hipotesis II

Terdapat hubungan langsung konsep diri terhadap kemampuan mengajar guru TK

3. Hipotesis III

Terdapat hubungan langsung kecerdasan emosi dan konsep diri terhadapkemampuan mengajar guru TK

\section{METODOLOGI PENELITIAN}

\section{Tujuan Penelitian}

Tujuan penelitian ini adalah untuk mengetahui:

1. Pengaruh langsung kecerdasan emosi $\left(X_{1}\right)$ terhadap kemampuan mengajar guru taman kanak-kanak (Y)

2. Pengaruh langsung konsep diri $\left(\mathrm{X}_{2}\right)$ terhadap kemampuan mengajar guru taman kanak-kanak (Y)

3. Pengaruh langsung kecerdasan emosi $\left(\mathrm{X}_{1}\right)$ dan konsep diri $\left(\mathrm{X}_{2}\right)$ terhadap kemampuan mengajar guru taman kanak-kanak (Y)

\section{Tempat dan Waktu Penelitian}

1) Tempat Penelitian

Penelitian ini dilaksanakan di Taman Kanak-Kanak se-Kecamatan Larangan, Tangerang.Terdiri dari 43 Taman KanakKanak dengan jumlah guru sebanyak 310 orang yang akan dijadikan responden penelitian.

2) Waktu Penelitian

Kegiatan penelitian ini akan memakan waktu selama tiga bulan terhitung mulai bulan november 2016-januari 2017. Pelaksanaan penelitian ini melalui 
beberapa tahap, yakni: (1) tahap persiapan

(2) pelaksanaan dan (3) tahap penyelesaian.

\section{Metode Penelitian}

Metode penelitian memandu peneliti tentang urutan-urutan bagaimana penelitian dilakukan. ${ }^{20}$ Metode merupakan cara utama untuk mencapai sesuatu, serta alat-alat tertentu. ${ }^{21}$ Penelitian tentang "Pengaruh Kecerdasan Emosi dan Konsep Diri terhadap Kemampuan Mengajar Guru Taman KanakKanak", penulis menggunakan metode Deskriptif dan Survey dengan korelasi sederhana dan korelasi ganda.

Metode Deskriptif adalah suatu metode dalam meneliti status sekelompok manusia, suatu objek, suatu set kondisi, suatu sistem penulisan, ataupun suatu kelas peristiwa pada masa sekarang. Tujuan dari penelitian deskriptif adalah untuk membuat deskripsi, gambaran atau lukisan secara sistematika, faktual dan aktual mengenai fakta-fakta, sifat-sifat serta hubungan antar fenomena yang di selidiki. ${ }^{22}$

Menurut Witney, metode deskriptif adalah pencarian fakta dengan interpretasi yang tepat. ${ }^{23}$ Metode deskriptif dapat dipandang sebagai suatu cara untuk memudahkan bagi peneliti, hal ini karena peneliti dapat :

a. Memusatkan diri pada pemecahan masalah yang ada pada saat sekarang dan pada masalah-masalah aktual.

b. Data yang dikumpulkan mula-mula disusun, dijelaskan dan kemudian dianalisa. ${ }^{24}$

Kerlinger mengemukakan bahwa Penelitian Survey adalah penelitian yang dilakukan pada populasi besar maupun kecil, tetapi data yang dipelajari adalah data dari sampel yang diambil dari populasi tersebut, sehingga ditemukan kejadian-kejadian relatif, distribusi dan hubungan-hubungan antar variabel, sosiologi maupun psikologis. ${ }^{25}$

${ }^{20}$ Moh. Nazir. 1999. Metode Penelitian. Jakarta : Ghalia Indonesia, h. 51.

${ }^{21}$ Winarno Surakhmad. 1980. Pengantar Penelitian Ilmia Pasar, Metode dan Tekhnik. Bandung: Alfabetha. h. 131.

${ }^{22}$ Moh. Nazir. Op. Cit., h. 54.

${ }^{23}$ Ibid., h. 55

${ }^{24}$ Winarno Surakhmad. Op. Cit., h. 140.

${ }^{25}$ Sugiyono. 2002. Metode Penelitian Administrasi.

Bandung : CV. Alfabetha., h. 7.
Metode Survey adalah penyelidikan yang diadakan untuk memperoleh fakta-fakta dari gejala-gejala yang ada dan mencari keteranganketerangan secara faktual, baik tentang intuisi sosial, ekonomi, atau politik dari suatu kelompok atau suatu daerah. ${ }^{26}$

Penelitian ini dilakukan dengan pendekatan kuantitatif yaitu penelitian yang didasarkan pada paradigma positivisme yang bersifat logico-hypotheco-verifikatif dengan berlandaskan pada asumsi-asumsi mengenai objek empiris. ${ }^{27}$

Dengan model konstelasi masalah dari variabel-variabel tersebut dapat dilihat dalam gambar berikut di bawah ini :

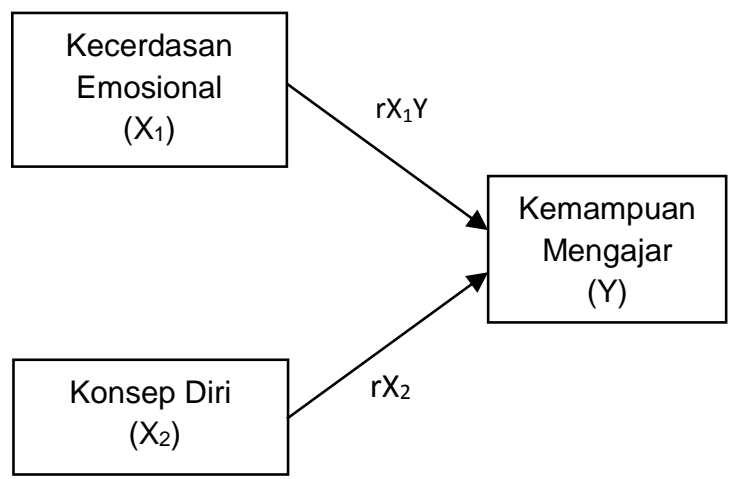

Gambar 1. Konstalasi Variabel Korelasi Sederhana dan Korelasi Ganda

Keterangan :

$\mathrm{X}_{1}$ : Kecerdasan Emosional

$\mathrm{X}_{2} \quad$ : Konsep Diri

Y : Kemampuan Mengajar

Dalam melakukan penelitian ini penulis menetapkan desain penelitian dengan langkahlangkah sebagai berikut :

a. Melakukan penjajakan ke lokasi penelitian, untuk mendapatkan gambaran masalah yang akan diteliti

b. Menentukan pokok (subjek) permasalahan awal

c. Melakukan pencarian dan pendalaman teori-teori dan konsep-konsep melalui sumber bacaan dan konsultasi dengan para ahli yang berhubungan dengan permasalahan penelitian.

d. Mengumpulkan, merangkum dan menyusun data, serta menganalisa data

\footnotetext{
${ }^{26}$ Moh. Nazir. Op. Cit., h. 56.

${ }^{27}$ Sugiyono. Op. Cit., h. 16.
} 
dan mendeskripsikannya dengan pendekatan kuantitatif.

\section{Populasi dan Sampling}

\section{Populasi Penelitian}

Suharsimi Arikunto mengatakan bahwa populasi adalah keseluruhan subjek penelitian. ${ }^{28}$ Populasi dalam penelitian ini adalah semua pihak baik manusia maupun non manusia (dokumentasi, simbol-simbol dan peralatan kerja) yang di pandang dengan memberikan data yang berhubungan dengan perilaku.

Menurut Sugiyono, populasi adalah wilayah generalisasi yang terdiri atas objek/subjek yang mempunyai kuantitas dan karakteristik tertentu yang ditetapkan oleh peneliti untuk dipelajari dan kemudian ditarik kesimpulannya. ${ }^{29}$ Sebuah populasi dengan jumlah individu tertentu dinamakan dengan populasi finit, sedangkan jumlah individu dalam kelompok tidak mempunyai jumlah yang tetap atau pun jumlah yang tidak terhingga disebut dengan populasi infinit. ${ }^{30}$ Populasi dalam penelitian ini adalah seluruh Guru Taman Kanak-Kanak seKecamatan Larangan yang berjumlah 310 orang.

\section{Sampel Penelitian}

Sampel adalah sebagian dari jumlah dan karakteristik yang di miliki oleh populasi tersebut. ${ }^{31}$ Sebuah sampel adalah bagian dari populasi. ${ }^{32}$ Dalam pengambilan sampel yang representatif menurut Ida Bagoes Mantra dan Kasto harus mempunyai sifat-sifat seperti di bawah ini : dipercaya dari seluruh populasi yang diteliti.
a. Dapat menghasilkan gambaran yang dapat
b. Dapat menentukan presisi (tingkat ketepatan) dari hasil penelitian dengan menentukan penyimpangan baku dari taksiran yang diperoleh.
c. Sederhana, hingga mudah dilaksanakan
d. Dapat memberikan keterangan sebanyak mungkin dengan biaya serendah- rendahnya. ${ }^{33}$

Dalam menentukan sampel, para ahli biasanya menggunakan probability sample. Probability sample adalah suatu sampel yang ditarik sedemikian rupa dimana suatu elemen (unsur) individu dari populasi, tidak didasarkan pada pertimbangan pribadi tetapi tergantung kepada aplikasi kemungkinan (probabilitas). ${ }^{34}$ Probability sampling adalah teknik sampling yang memberikan peluang yang sama bagi setiap unsur (anggota) populasi untuk dipilih menjadi anggota sampel. ${ }^{35}$

Sehubungan dengan hal tersebut, maka teknik pengambilan sampel yang digunakan dalam penelitian ini adalah teknik multiy state random sampling, maksudnya tiap unsur tingkatan sampel secara beberapa tingkat memiliki peluang dan kesempatan yang sama untuk dipilih. Sampel yang menggunakan seluruh populasi disebut sampel batas atau sensus, penggunaan ini berlaku jika anggota populasi relatif kecil, untuk anggota pulasi yang relatif besar bisa mengambil sampel sebagian anggota populasi yang merupakan sebagian anggota populasi.

Menurut Sugiyono, makin besar jumlah sampel mendekati populasi, maka peluang kesalahan generalisasi makin kecil dan sebaliknya makin kecil jumlah sampel menjauhi populasi maka semakin besar kesalahan generalisasi (diberlakukan umum). ${ }^{36}$ Arikunto berpendapat bahwa apabila objeknya kurang dari 100, maka sebaiknya diambil semuanya. Selanjutnya apabila objeknya lebih besar dari 100 maka dapat diambil $10-15 \%$ atau $20-25 \%$ atau lebih, tergantung setidak-tidaknya dari :

a. Kemampuan peneliti dilihat dari waktu, tenaga dan dana

b. Sempit luasnya wilayah pengamatan dari setiap subjek, karena hal itu menyangkut banyak sedikitnya data.

c. Besar kecilnya resiko yang ditanggung oleh peneliti, untuk penelitian yang

\footnotetext{
${ }^{33}$ Sudjana. 1996. Metode Statistik. Bandung :

Tarsito., h. 6.

${ }^{34}$ Moh. Nazir. Log. Cit.

${ }^{35}$ Sugiyono. Op. Cit., h. 92.

${ }^{36}$ Ibid., h. 97.

${ }^{28}$ Suharsimi Arikunto. 1997. Prosedur Penelitian.

Jakarta : Rineka CIpta, h. 108.

${ }^{29}$ Sugiyono. Op. Cit., h. 90.

${ }^{30}$ Moh. Nazir. Op. Cit., h. 271.

${ }^{31}$ Sugiyono. Log. Cit., h. 91.

${ }^{32}$ Moh. Nazir. Log. at., h. 271
} 
berisiko besar tentu saja jika sampel besar hasilnya akan lebih baik. ${ }^{37}$

Sampel dalam penelitian ini diambil dengan menggunakan cara multiy state random sampling, maksudnya tiap unsur tingkatan sampel secara beberapa tingkat memiliki peluang dan kesempatan yang sama untuk dipilih. Dari jumlah 310 orang guru yang ada di TK Kecamatan Larangan diambil $18 \%$ sebagai sampel dan diperoleh sampel sebanyak 55 orang guru.

\section{Teknik Pengumpulan Data}

Instrumen penelitian disusun sendiri oleh peneliti secara konstruktif berdasarkan kesimpulan dari kajian teoretik yang diturunkan menjadi kisi-kisi instrumen. Instrumen untuk pengumpul data dalam penelitian ini terdiri dari tiga instrumen untuk tiga variabel, yaitu variabel kecerdasan emosional, konsep diri dan kemampuan mengajar. Instrumen masingmasing variabel akan dirinci sebagai berikut:

\section{Variabel Kemampuan Mengajar}

a. Definisi Konseptual

Kemampuan mengajar adalah kompetensi yang dimiliki guru dalam mentransfer pengetahuan untuk mencapai tujuan pembelajaran.

b. Definisi Operasional

Kemampuan mengajar adalah skor yang diperoleh guru dari hasil penilaian kemampuan guru.

c. Kisi-kisi Kemampuan Mengajar Guru
Tabel 1. Kisi-Kisi Instrumen Kemampuan Mengajar

\begin{tabular}{|c|c|c|c|c|}
\hline No & Dimensi & Indikator & $\begin{array}{c}\text { Nomor } \\
\text { Butir }\end{array}$ & Jumlah \\
\hline 1 & Persiapan & $\begin{array}{l}\text { a. Perumusan } \\
\text { tujuan } \\
\text { b. Pemilihan } \\
\text { metode } \\
\text { c. Pengalaman } \\
\text { mengajar }\end{array}$ & $\begin{array}{l}1,2,3,4,5,6 \\
, 7,8,9,10\end{array}$ & 10 \\
\hline 2 & Pelaksanaan & $\begin{array}{l}\text { a. Metode } \\
\text { b. Strategi } \\
\text { belajar } \\
\text { c. Media -Alat } \\
\text { Peraga }\end{array}$ & $\begin{array}{c}11,12,13,1 \\
4,15,16,17 \\
18,19,20\end{array}$ & 10 \\
\hline 3 & Evaluasi & $\begin{array}{l}\text { a. Penilaian } \\
\text { siswa } \\
\text { b. Perencanaan } \\
\text { kegiatan } \\
\text { berikutnya }\end{array}$ & $\begin{array}{c}21,22,23,2 \\
4,25,26,27 \\
, 28,29,30\end{array}$ & 10 \\
\hline
\end{tabular}

d. Kalibrasi Instrumen

Untuk mendapatkan data tentang kemampuan mengajar digunakan 30 butir pertanyaan/pernyataan yang merupakan penjabaran dari komposisi kemampuan mengajar guru. Skor diatur berdasarkan skala likert yang diimplementasikan dalam tiga opsi, untuk pernyataan positif ; SL yang berarti selalu, memiliki skor 5, SR yang berarti sering memiliki skor 4, KD yang berarti kadangkadang memiliki skor 3.

Instrumen penelitian tentang kemampuan mengajar guru disusun berdasarkan konsep teori yang melandasinya, selanjutnya diujicobakan secara random kepada guru.Ujicoba instrumen dilakukan untuk mengetahui validitas dan reliabilitas instrumen yang digunakan. Menguji validitas dan reliabilitas instrumen maksudnya untuk mengukur valid tidaknya instrumen itu. Instrumen yang valid berarti instrumen tersebut layak digunakan sebagai alat ukur, yakni dapat digunakan untuk mengukur apa yang hendak diukur. Instrumen yang reliabel berarti instrumen yang apabila digunakan beberapa kali untuk mengukur objek yang sama akan menghasilkan data yang sama.

Pengujian taraf validitas instrumen dilakukan dengan menggunakan rumus korelasi product moment $^{38}$, yaitu:

\footnotetext{
${ }^{37}$ Suharsimi Arikunto. Op. Cit., h. 112.
} 


$$
r=\frac{n \sum x Y-\left(\sum x\right)\left(\sum Y\right)}{\sqrt{\left\{n\left(\Sigma x^{2}\right)-(\Sigma x)^{2}\right\} n\left(\Sigma Y^{2}\right)-(\Sigma Y)^{2}}}
$$

Selanjutnya, Singaribun mengatakan bahwa secara statistik angka korelasi yang diperoleh harus dibandingkan dengan angka kritik tabel korelasi nilai kritis product moment. Apabila $\mathrm{r}$ hitung lebih besar dari $r$ tabel $\left(r_{n}>r_{t}\right)$ maka item soal dianggap valid. ${ }^{39}$

Untuk pengujian reliabilitas instrumen yang digunakan rumus Alpha Cronbach yaitu :

Reliabilitas

$$
\mathrm{r}_{\mathrm{ii}}=\left(\begin{array}{c}
\mathrm{k} \\
\mathrm{k}-1
\end{array}\right) \quad\left(\begin{array}{ll}
1- & \frac{\square \mathrm{si}^{2}}{\mathrm{st}^{2}}
\end{array}\right)
$$

Keterangan :

$\mathrm{r}_{11} \quad$ : reliabilitas instrumen

$\mathrm{k}$ : banyaknya butir pertanyaan atau banyaknya soal

$\sum \mathrm{s}_{1}{ }^{2} \quad$ : jumlah varians butir

$\mathrm{st}^{2} \quad$ : varians total

Tabel 2. Pedoman Untuk Memberikan Interpretasi Nilai Koefisien Korelasi ${ }^{40}$

\begin{tabular}{cl}
\hline Interval koefisien & \multicolumn{1}{c}{ Tingkat hubungan } \\
\hline $\mathbf{0 , 0 0}-\mathbf{0 , 1 9 9}$ & Sangat rendah \\
$\mathbf{0 , 2 0}-\mathbf{0 , 3 9 9}$ & Rendah \\
$\mathbf{0 , 4 0}-\mathbf{0 , 5 9 9}$ & Sedang \\
$\mathbf{0 , 6 0}-\mathbf{0 , 7 9 9}$ & Kuat \\
$\mathbf{0 , 8 0}-\mathbf{1 . 0 0 0}$ & Sangat kuat \\
\hline
\end{tabular}

\section{Variabel Kecerdasan Emosi}

a. Definisi Konseptual

Kecerdasan emosional adalah kecakapan yang dimiliki oleh seseorang dalam hal pengendalian diri, pengelolaan stress, berempati dan membina hubungan antar sesama.

b. Definisi Operasional

Kecerdasan emosional adalah skor yang diperoleh dari hasil penyebaran instrumen kecerdasan emosional.

\footnotetext{
${ }^{39}$ Masri Singaribun. Et. All. 1999.

Metodologi Penelitian Survey. Jakarta : LP3ES., h. 139.

${ }^{40}$ Sugiyono. Op. Cit., h. 214.
}

Kisi-kisi Instrumen $\quad$ Kecerdasan
Emosional

\begin{tabular}{|c|c|c|c|c|}
\hline No & Dimensi & Indikator & $\begin{array}{c}\text { Nomor } \\
\text { Butir }\end{array}$ & Jumlah \\
\hline 1 & $\begin{array}{l}\text { Kesadaran } \\
\text { Diri }\end{array}$ & $\begin{array}{l}\text { a. Kesadaran } \\
\text { Emosi } \\
\text { b. Penilaian Diri } \\
\text { c. Percaya Diri }\end{array}$ & $1,2,3,4,5,6$ & 6 \\
\hline 2 & $\begin{array}{l}\text { Pengaturan } \\
\text { Diri }\end{array}$ & $\begin{array}{l}\text { a. Kendali Diri } \\
\text { b. Sifat dapat } \\
\text { dipercaya } \\
\text { c. Kewaspadaan } \\
\text { d. Adaptabilitas } \\
\text { e. Inovasi }\end{array}$ & $\begin{array}{l}7,8,9,10,1 \\
1,12\end{array}$ & 6 \\
\hline 3 & Motivasi Diri & $\begin{array}{l}\text { a. Dorongan } \\
\text { berprestasi }\end{array}$ & $\begin{array}{l}13,14,15,1 \\
6,17,18\end{array}$ & 6 \\
\hline 4 & $\begin{array}{l}\text { Turut } \\
\text { Merasakan } \\
\text { (Empati) }\end{array}$ & $\begin{array}{l}\text { a. Memahami } \\
\text { Orang Lain } \\
\text { b. Orientasi } \\
\text { pelayanan } \\
\text { c. Mengatasi } \\
\text { keragaman }\end{array}$ & $\begin{array}{l}19,20,21,2 \\
2,23,24\end{array}$ & 6 \\
\hline 5 & $\begin{array}{l}\text { Keterampilan } \\
\text { Sosial }\end{array}$ & $\begin{array}{l}\text { a. Komunikasi } \\
\text { b. Manajemen } \\
\text { Konflik } \\
\text { c. Kemampuan } \\
\text { tim }\end{array}$ & $\begin{array}{l}25,26,27,2 \\
8,29,30\end{array}$ & 6 \\
\hline
\end{tabular}

Tabel 3. Kisi-kisi instrumen penelitian

a. Kalibrasi Instrumen

Untuk mendapatkan data tentang kecerdasan emosional guru digunakan angket yang terdiri dari 30 butir pertanyaan/pernyataan yang merupakan penjabaran dari kecerdasan emosional. Setelah instrumen penelitian tentang kecerdasan emosional guru disusun, selanjutnya diujicobakan secara random kepada kepala TK. Ujicoba dilakukan untuk mengetahui validitas dan reliabilitas instrumen yang digunakan.

Untuk mengetahui validitas angket digunakan formula korelasi product moment, sedangkan untuk mengetahui reliabilitas angket digunakan formula Alpha Cronbach.

\section{Variabel Konsep Diri}

a. Definisi Konseptual

Konsep diri adalah pandangan, perasaan, dan penilaian kita tentang diri kita sendiri yang meliputi fisik, keluarga, pribadi, moral etik, dan sosial. 
b. Definisi Operasional

Konsep diri adalah skor yang diperoleh dari skor semua data responden yang berisi tentang konsep diri.

c. Kisi-kisi Intrumen Penelitian Konsep Diri

Tabel 4. Kisi-Kisi Instrumen Penelitian Konsep Diri

\begin{tabular}{|c|c|c|c|c|}
\hline No & Dimensi & Indikator & $\begin{array}{c}\text { Nomor } \\
\text { Butir }\end{array}$ & Jumlah \\
\hline 1 & Persepsi/ Fisik & $\begin{array}{l}\text { a. Gaya Bahasa } \\
b . \quad \text { Body } \\
\text { Language } \\
\text { c. Kesehatan }\end{array}$ & $\begin{array}{c}1,2,3,4,5,6 \\
, 7,8,9,10\end{array}$ & 10 \\
\hline 2 & $\begin{array}{c}\text { Konsepsi } \\
\text { /Psikologis }\end{array}$ & $\begin{array}{ll}\text { a. } & \text { Motivasi } \\
\text { b. } & \text { Sabar } \\
\text { c. } & \text { Interpersonal } \\
\text { d. } & \text { Intrapersonal }\end{array}$ & $\begin{array}{r}11,12,13,1 \\
4,15,16,17 \\
, 18,19,20\end{array}$ & 10 \\
\hline 3 & Sikap & $\begin{array}{l}\text { a. Tanggung } \\
\text { jawab } \\
\text { b. Mandiri dalam } \\
\text { keputusan } \\
\text { c. Disiplin } \\
\text { d. Wibawa } \\
\text { e. Ketaatan } \\
\text { pada atasan } \\
\text { f. Kehadiran } \\
\text { g. Setia pada } \\
\text { landasan dan } \\
\text { ketentuan hukum }\end{array}$ & $\begin{array}{r}21,22,23,2 \\
4,25,26,27 \\
, 28,29,30\end{array}$ & 10 \\
\hline
\end{tabular}

\section{d. Kalibrasi Instrumen}

Untuk mendapatkan data tentang konsep diri guru, digunakan angket yang terdiri dari 30 butir pertanyaan/pernyataan yang merupakan penjabaran dari konsep diri guru TK. Setelah instrumen penelitian konsep diri disusun, selanjutnya diujicobakan secara random kepada Kepala TK. Ujicoba dilakukan untuk mengetahui validitas dan reliabilitas instrumen yang digunakan.

Untuk mengetahui validitas angket digunakan formula korelasi product moment, sedangkan untuk mengetahui reliabilitas angket digunakan formula Alpha Cronbach.

\section{Teknik Analisa Data}

Data yang diperoleh dalam penelitian ini diperoleh melalui hasil penyebaran angket. Dalam menganalisa data diarahkan pada pengujian hipotesis, yang diawali dengan deskripsi data penelitian dari ketiga variabel dalam bentuk distribusi frekuensi dan histogramnya serta menentukan persamaan regresinya. Sebagai syarat untuk pengujian data penelitian, dilakukan:
1. Uji Normalitas

Karena statistik parametrik berlandaskan pada asumsi bahwa data yang akan dianalisis harus berdistribusi normal, maka penulis menggunakan uji normalitas untuk mengetahui apakah suatu data yang dihasilkan berdistribusi normal atau tidak, melalui uji Liliforce ${ }^{41}$, dengan menentukan nilai Lo sebagai berikut :

$$
\mathrm{L}_{\mathrm{o}}=\mathrm{IF}_{(\mathrm{z})}-\mathrm{S}_{(\mathrm{z})} \mathrm{I}
$$

Harus perhitungan tersebut lalu dibandingkan dengan nilai $\mathrm{L}_{1}$ dari tabel Liliforce. Jika $\mathrm{L}_{0}<\mathrm{L}_{1}$, maka sampel berasal dari populasi berdistribusi normal.

\section{Uji Homogenitas}

Uji homogenitas dilakukan untuk menguji apakah data yang dianalisa berasal dari populasi yang homogen atau tidak. Dalam pengujian ini menggunakan uji Bartlet ${ }^{42}$, dengan menggunakan persamaan :

$$
\chi^{2}=(\operatorname{in} 10)\left\{\mathrm{B}-\left(\sum d b \log \mathrm{S}_{1}^{2}\right.\right.
$$

Untuk taraf nyata $\alpha=0,05$, kemudian kita bandingkan dengan nilai $\chi_{t}^{2}$ pada tabel. Jika $\chi_{h}^{2}<\chi_{t}^{2}$, maka sampel berasal dari populasi homogen.

\section{Uji Signifikasi dan Linieritas Regresi}

Untuk memperoleh estimasi dan signifikansi data yang diperoleh dilakukan dengan analisis statistik univariate. Analisis univariate dimaksudkan untuk mendapatkan deskripsi tentang masing-masing variabel, sedangkan analisis bivariate untuk mengungkapkan signifikasi kualitas hubungan dan korelasi dua variabel.

Berdasarkan harga statistik yang diperoleh dapat disimpulkan erat tidaknya tingkat hubungan antara ketiga variabel termasuk besar kecilnya kontribusi antara variabel tersebut.

Untuk menguji signifikansi hubungan antara variabel menggunakan uji keberartian Koefisien Korelasi (uji-t), sebagai berikut :

\footnotetext{
${ }^{41}$ Santosa Murwani. 2000. Statistika Terapan. Jakarta: UHAMKA, h.20

${ }^{42}$ Ibid, h. 22
} 


$$
t=\frac{r \sqrt{n-2}}{\sqrt{1-r^{2}}}
$$

Harga $\mathrm{t}$ selanjutnya dibandingkan dengan $\mathrm{t}$ table, dengan taraf nyata 0,05 dan (n-2), apabila t hitung > t tabel, maka koefisiensi korelasi signifikansi (berarti). Untuk mengetahui (koefisien determinasi) variansi variabel terikat yang dijelaskan oleh variabel bebas melalui regresi linier adalah dengan mengkuadratkan nilai t.

Untuk menentukan koefisien korelasi parsial digunakan rumus :

$$
r_{y 12}=\frac{r_{y 1}-\left\{r_{y 2} x r_{12}\right\}}{\left.\sqrt{\left\{1-r_{y 2}^{2}\right.}\right\}\left\{1-r_{t 2}{ }^{2}\right\}}
$$

Regresi digunakan untuk memprediksikan seberapa jauh nilai variabel dependen bila nilai variabel independen dirubah. Sugiyono ${ }^{43}$ mengemukakan bahwa regresi digunakan untuk menganalisis antara satu dengan variabel yang lain secara konseptual mempunyai hubungan kausal atau fungsional.

Uji signifikansi regresi ${ }^{44}$ dilakukan dengan menggunakan persamaan berikut :

$$
F_{h}=\frac{J K(r e g)}{J K(S) /(n-2)}
$$

Harga $F_{h}$ tersebut dibandingkan dengan $F_{t}$, apabila $F_{h}>F_{t}$, maka koefisien regresi signifikan dan pengujian linieritas regresi dilakukan dengan menggunakan persamaan :

$$
F_{h}=\frac{J K(T C) /(k-2)}{J K(G) /(n-k)}
$$

Kemudian hasil $\mathrm{F}_{\mathrm{h}}$ dibandingkan dengan $\mathrm{F}_{\mathrm{t}}$, dan apabila $F_{h}<F_{t}$, maka koefisien regresi linier. Selanjutnya uji signifikansi regresi ganda dilakukan dengan menggunakan persamaan:

\footnotetext{
${ }^{43}$ Sugiyono. 2002. Metode Penelitian Administrasi. Bandung : Alfabeta, h.90

${ }^{44}$ Santosa Muwarni, op.cit, h. 40
}

$$
F_{h}=\frac{J K(r e g) / 2}{J K(S) /(n-3)}
$$

Setelah $\mathrm{F}_{\mathrm{h}}$ dikonsultasikan dengan $\mathrm{F}_{\mathrm{t}}$, dan apabila $F_{h}>F_{t}$, maka koefisien regresi ganda signifikansi. Analisa data meliputi statistik deskriptif dan inferensial. Statistik deskriptif meliputi perhitungan rata-rata, median, modus, strandar deviasi,varians dan pendekatan tabel distribusi frekuensi dan histogram.

Statistik inferensial untuk pengujian hipotesis penelitian ini dilakukan dengan menggunakan metode statistik korelasi regresi sederhana dan korelasi regresi ganda. Penggunaan teknik regresi melalui beberapa persyaratan yang harus dipenuhi yaitu:sampel diambil acak,dan sampel diambil dari populasi yang berdistribusi normal.

\section{Hipotesis Statistik}

Hipotesis statistik penelitian adalah :

1. Ho : $\mathrm{p}_{1} \mathrm{y}=0$

$\mathrm{H}_{1}: \mathrm{p} \mathrm{x}_{1} \mathrm{y}>0$

2. Ho: $\mathrm{p}_{2} \mathrm{y}=0$

$\mathrm{H}_{1}: \mathrm{p} \mathrm{x}_{2} \mathrm{y}>0$

3. Ho $: R y_{12}=0$

$\mathrm{H}_{1}: \mathrm{Ry}_{12}>0$

Keterangan:

$\mathrm{H}_{\mathrm{o}}$ : Hipotesi $\mathrm{Nol}$

$\mathrm{H}_{1}$ : Hipotesis Altenatif

$\mathrm{Py}_{1}$ : Koefisien korelasi $\mathrm{x}_{1}$ dengan $\mathrm{y}$

$\mathrm{Py}_{2}$ : Koefisien korelasi $\mathrm{x}_{2}$ dengan $\mathrm{y}$

$\mathrm{Ry}_{12}$ : Koefisien korealsi ganda $\mathrm{x}_{1}$ dan $\mathrm{x}_{2}$ dengan $\mathrm{y}$

\section{HASIL PENELITIAN}

\section{Deskripsi Data}

Deskripsi data dari hasil penelitian bertujuan untuk memberikan gambaran umum mengenai penyebaran/ distribusi data, baik yang berupa ukuran gejala sentral, ukuran letak dan distribusi frekwensi. Harga-harga yang disajikan setelah diolah dari data mentah dengan menggunakan metode statistik deskriptif. Data penelitian ini terdiri dari: Kemampuan Mengajar Guru TK (Y) sebagai variabel terikat, Kecerdasan Emosi $\left(\mathrm{X}_{1}\right)$ dan Konsep Diri $\left(\mathrm{X}_{2}\right)$ sebagai variabel bebas. Untuk masing-masing variabel di bawah ini akan disajikan nilai rata-rata, simpangan 


\section{Kemampuan Mengajar Guru TK}

Berdasarkan hasil penelitian untuk skor Kemampuan Mengajar Guru TK mempunyai rentang skor empiris 39, dengan skor terendah 60 dan skor tertinggi 99. Dari analisis data diketahui $\bar{X}=73,94, \mathrm{SD}=8,93$. Selanjutnya banyaknya kelas 7 dan panjang kelas 6 serta distribusi frekwensi sebagaimana terlihat pada tabel 5.Dari data yang terkumpul diperoleh harga-harga sebagai berikut:

Jumlah sampel $(\mathrm{n})=55$

Banyak kelas $(\mathrm{k})=1+(3,3)(\log 55)$

$$
\begin{aligned}
& =1+(3,3)(1.74) \\
& =7,48(\text { dibulatkan menjadi } 7)
\end{aligned}
$$

Rentang kelas (R) $=99-60=39$

Panjang kelas $(\mathrm{p})=39 / 7=5,57$ (dibulatkan menjadi 6)

Tabel 5. Distribusi Frekwensi Skor Kemampuan Mengajar Guru TK

\begin{tabular}{cccc}
\hline No & Skor & $\begin{array}{c}\text { Frek. } \\
\text { Absolut }\end{array}$ & $\begin{array}{c}\text { Frek. Relatif } \\
(\%)\end{array}$ \\
\hline 1 & $60-66$ & 2 & 3.64 \\
2 & $67-73$ & 17 & 30.91 \\
3 & $74-80$ & 11 & 20.00 \\
4 & $81-87$ & 14 & 25.45 \\
5 & $88-94$ & 8 & 14.55 \\
6 & $95-101$ & 3 & 5.45 \\
7 & $102-108$ & 0 & 0.00 \\
\multicolumn{2}{c}{ Jumlah } & $\mathbf{5 5}$ & $\mathbf{1 0 0}$ \\
\hline
\end{tabular}

Berdasarkan perhitungan yang tertera pada tabel 5, didapat 45,45\% (25 orang) memperoleh skor Kemampuan Mengajar Guru TK di atas rata-rata, $20,00 \%$ (11 orang) pada rata-rata dan $34,55 \%$ (17 orang) di bawah rata-rata Histogram data tabel 5 diperlihatkan pada gambar 1.

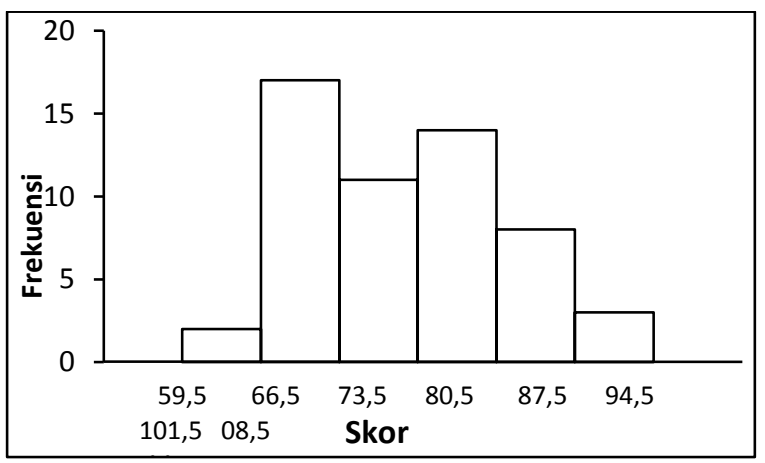

Gambar 1. Histogram Skor Kemampuan Mengajar Guru TK

\section{Kecerdasan Emosi}

Berdasarkan hasil penelitian untuk skor hasil Kecerdasan Emosi mempunyai rentang skor empiris 40, dengan skor terendah 65 dan skor tertinggi 105. Dari analisis data diketahui $\bar{X}=$ $85,16, \mathrm{SD}=10,07$. selanjutnya banyaknya kelas 7 dan panjang kelas 6 serta distribusi frekwensi sebagaimana terlihat pada tabel 6 . Dari data yang terkumpul diperoleh hargaharga sebagai berikut:

Jumlah sampel $(\mathrm{n})=55$

Banyak kelas $(\mathrm{k})=1+(3,3)(\log 55)$

$$
=1+(3,3)(1.74)
$$$$
=7,48 \text { (dibulatkan menjadi 7) }
$$

Rentang kelas $(\mathrm{R}) \quad=105-65=40$

Panjang kelas (p) $\quad=40 / 7=$

(dibulatkan menjadi 6)

Tabel 6. Distribusi Frekuensi Skor Hasil Kecerdasan Emosi

\begin{tabular}{cccc}
\hline No & Skor & $\begin{array}{c}\text { Frek. } \\
\text { Absolut }\end{array}$ & $\begin{array}{c}\text { Frek. } \\
\text { Relatif (\%) }\end{array}$ \\
\hline 1 & $65-71$ & 4 & 7.27 \\
2 & $72-78$ & 8 & 14.55 \\
3 & $79-85$ & 18 & 32.73 \\
4 & $86-92$ & 12 & 21.82 \\
5 & $93-99$ & 8 & 14.55 \\
6 & $100-106$ & 5 & 9.09 \\
7 & $107-113$ & 0 & 0.00 \\
Jumlah & & 55 & 100 \\
\hline
\end{tabular}

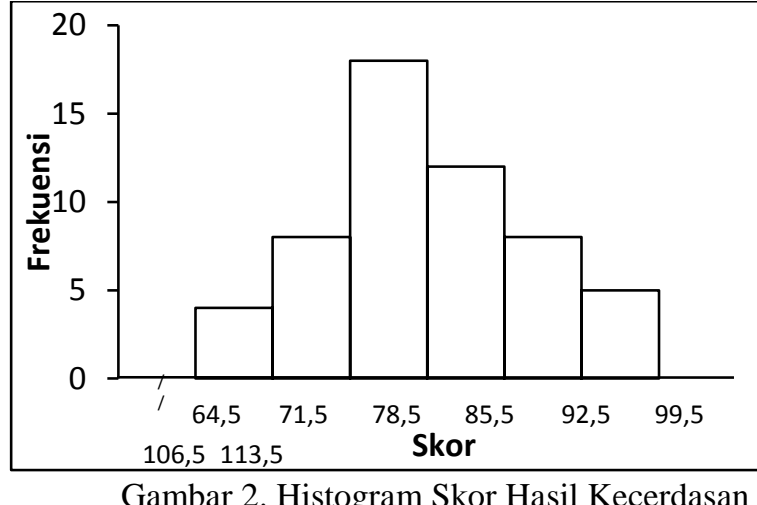

Emosi

Berdasarkan perhitungan yang tertera pada tabel 6, didapat 23,64\% (13 orang) memperoleh skor hasil Kecerdasan Emosi di atas rata-rata, $21,82 \%$ (12 orang) pada rata-rata dan $54,55 \%$ (30 orang) di bawah rata-rata. Histogram data tabel 6 diperlihatkan pada gambar 2 . 


\section{Konsep Diri}

Berdasarkan hasil penelitian untuk skor hasil tes Konsep Diri mempunyai rentang skor empiris 27, dengan skor terendah 60 dan skor tertinggi 87. Dari analisis data diketahui $\bar{X}=$ $73,94, \mathrm{SD}=6,52$ selanjutnya banyaknya kelas 7 dan panjang kelas 4 serta distribusi frekwensi sebagaimana terlihat pada tabel 7. Dari data yang terkumpul diperoleh harga-harga sebagai berikut:

Jumlah sampel $(\mathrm{n})=55$

Banyak kelas $(\mathrm{k}) \quad=1+(3,3)(\log 55)$

$=1+(3,3)(1.74)$

$=7,48$ (dibulatkan menjadi

7)

Rentang kelas $(\mathrm{R})=87-60=27$

Panjang kelas $(\mathrm{p})=27 / 7=3,91$ (dibulatkan menjadi 4)

Berdasarkan perhitungan yang terdapat pada tabel 7, didapat 20,00\% (11 orang) memperoleh skor Konsep Diri di atas rata-rata, 25,45\% (14 orang) pada rata-rata dan $54,55 \%$ (30 orang) di bawah rata-rata Histogram data tabel 7 diperlihatkan pada gambar 16.

Tabel 7. Distribusi Frekuensi Skor Konsep Diri

\begin{tabular}{cccc}
\hline No & Skor & $\begin{array}{c}\text { Frek. } \\
\text { Absolut }\end{array}$ & $\begin{array}{c}\text { Frek. } \\
\text { Relatif } \\
(\%)\end{array}$ \\
\hline 1 & $60-64$ & 4 & 7.27 \\
2 & $65-69$ & 10 & 18.18 \\
3 & $70-74$ & 16 & 29.09 \\
4 & $75-79$ & 14 & 25.45 \\
5 & $80-84$ & 9 & 16.36 \\
6 & $85-89$ & 2 & 3.64 \\
7 & $90-94$ & 0 & 0 \\
\hline Jumlah & & 55 & 100 \\
\hline
\end{tabular}

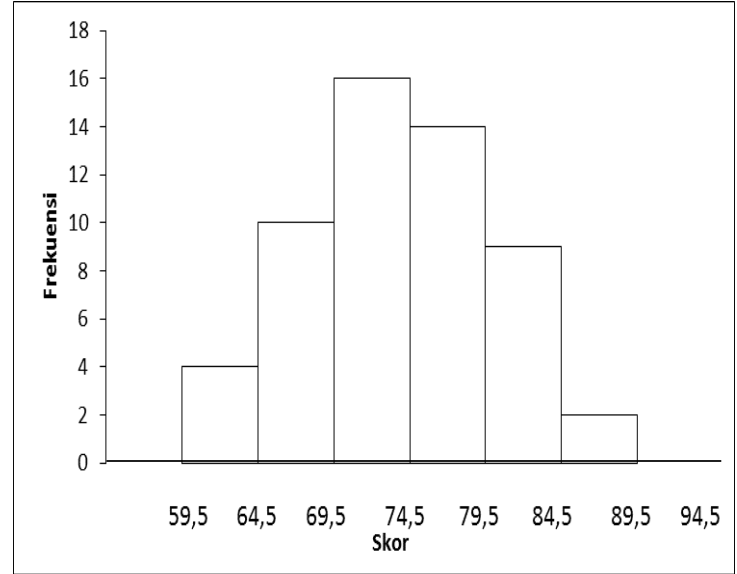

Gambar 3. Histogram Skor Konsep Diri

\section{Pengujian Persyaratan Analisis}

Sepengaruh dengan desain penelitian pada pembahasan terdahulu yang terdiri dari dua variabel bebas $X_{1}, X_{2}$ dan satu variabel terikat $\mathrm{Y}$, maka teknik analisis data yang relevan adalah regresi dan korelasi sederhana dan korelasi ganda (pada penelitian ini menggunakan program SPSS 17).

Sebelum data diolah dengan teknik yang dimaksud maka terlebih dahulu dilakukan pengujian persyaratan analisis. Apabila persyaratan tidak terpenuhi maka harus dipilih analisis statistik yang lain, namun bila persyaratan tersebut terpenuhi maka analisis regresi dan korelasi dapat diajukan.

Beberapa persyaratan yang harus dipenuhi sebelum dilakukan analisis regresi dan korelasi, yaitu;

1. Sampel diambil dengan cara acak dan ditentukan berdasarkan ukuran sampel (n) minimum.

2. Berdistribusi normal dengan rata-rata nol dan varians $\sigma_{\text {yx. }}^{2}$

3. Untuk tiap kelompok $\mathrm{X}$ yang diketahui, varians $\sigma_{\mathrm{yx}}^{2}$ dimisalkan sama/ homogen.

Untuk persyaratan pertama yaitu sampel diambil secara acak (random sampling). Hal ini terpenuhi sebagaimana yang telah dijelaskan teknik pengambilan sampel pada bab III. Untuk persyaratan kedua yaitu normalitas dan persyaratan ketiga yaitu homogenitas varians $\mathrm{Y}$ berdasarkan pengelompokan X. Adapun pengujian sebagai berikut: 


\section{Pengujian Normalitas}

Pengujian normalitas dalam penelitian ini menggunakan Uji Liliefors. Pengujian normalitas ini dimaksudkan untuk mengetahui apakah data berdistribusi normal atau tidak dengan hipotesisi statistiknya sebagai berikut:

$\mathrm{H}_{\mathrm{o}}=$ Data populasi berdistribusi normal

$\mathrm{H}_{1}=$ Data populasi berdistribusi tidak normal

Kriteria pengujian adalah $\mathrm{H}_{\mathrm{o}}$ jika hasil perhitungan $\mathrm{L}_{\mathrm{o}}$ maksimal < dari $\mathrm{L}_{\text {tabel }}$ dengan taraf signifikansi yang digunakan sebagai dasar untuk menolak atau menerima keputusan berdistribusi normal atau tidak adalah $\alpha=0.05$. Hasil perhitungan dapat dilihat pada tabel 8 . Perhitungan lengkap dapat dilihat pada lampiran.

Tabel 8. Hasil Pengujian Normalitas Data

\begin{tabular}{|c|c|c|c|c|c|}
\hline $\begin{array}{l}\text { Va } \\
\text { ria } \\
\text { bel } \\
\end{array}$ & $\mathbf{N}$ & $\alpha$ & $\mathbf{L}_{\text {hitung }}$ & $\mathbf{L}_{\text {tabel }}$ & $\begin{array}{c}\text { Distri } \\
\text { busi }\end{array}$ \\
\hline$X_{1}$ & 30 & 0.05 & 0.052 & 0.119 & $\begin{array}{c}\text { Norm } \\
\text { al }\end{array}$ \\
\hline$X_{2}$ & 30 & 0.05 & 0,054 & 0.119 & $\begin{array}{c}\text { Norm } \\
\text { al }\end{array}$ \\
\hline $\mathrm{Y}$ & 30 & 0.05 & 0.105 & 0.119 & $\begin{array}{c}\text { Norm } \\
\text { al }\end{array}$ \\
\hline
\end{tabular}

Keterangan:

Y : Kemampuan Mengajar Guru TK

$\mathrm{X}_{1} \quad$ : Kecerdasan Emosi

$\mathrm{X}_{2} \quad$ : Konsep Diri

Hasil perhitungan sebagaimana digambarkan pada tabel 8 di atas, diperoleh $\mathrm{L}_{\mathrm{o}}$ untuk seluruh kelompok sampel lebih kecil dibanding dengan L. Dengan demikian dapat disimpulkan bahwa sampel berasal dari populasi berdistribusi normal.

\section{Pengujian Homogenitas}

Uji homogenitas menggunakan uji Bartlett untuk taraf keempat variabel penelitian dengan taraf signifikansi $\alpha=0,05$. Data Kemampuan Mengajar Guru TK (Y), Kecerdasan Emosi $\left(\mathrm{X}_{1}\right)$ dan Konsep Diri $\left(\mathrm{X}_{2}\right)$, untuk pengujian hipotesis nol menempuh langkah-langkah sebagai berikut. Ringkasan hasil uji homogenitas dapat dilihat pada tabel 9 . Perhitungan lengkap dapat dilihat pada lampiran.
Tabel 9. Rangkuman Hasil Uji Homogenitas

\begin{tabular}{ccccc} 
Variabel & $\mathrm{K}$ & $\mathrm{X}_{\mathrm{h}}^{2}$ & $\mathrm{X}_{\mathrm{t}}^{2}$ & Kesimpulan \\
\hline $\mathbf{Y}$ & & & & \\
$\mathbf{X}_{\mathbf{1}}$ & 54 & 7,80 & 7,81 & Homogen \\
$\mathbf{X}_{\mathbf{2}}$ & & & & \\
\hline
\end{tabular}

Keterangan:

Y : Kemampuan Mengajar Guru TK

$\mathrm{X}_{1} \quad$ : Kecerdasan Emosi

$\mathrm{X}_{2} \quad$ : Konsep Diri

Hasil perhitungan sebagaimana digambarkan pada tabel 9 di atas, diperoleh $X^{2} h=7,80$ lebih kecil dibanding dengan $X_{t}^{2}=7,81$. Sehingga Ho: diterima dalam taraf nyata $\alpha=0,05$. Dengan demikian dapat disimpulkan bahwa ketiga variabel mempunyai varians yang sama besar (homogen).

\section{Pengujian Hipotesis}

Sepengaruh dengan perumusan masalah yang telah diajukan pada bab II terdapat 3 hipotesis yang akan diuji dengan menggunakan statistik inferensial yaitu statistik analisis regresi, korelasi sederhana dan korelasi ganda. Adapun analisis variabel bebas dengan variabel terikat dengan menggunakan koefisien korelasi product moment dari Person, sedangkan pengujian yang menyatakan pengaruh secara bersama-sama $X_{1}$ dan, $X_{2}$ dilakukan dengan menggunakan teknik analisis regresi dan korelasi ganda (dengan Program SPSS 17).

Hubungan antara Kecerdasan Emosi $\left(\mathbf{X}_{1}\right)$ dengan Kemampuan Mengajar Guru TK (Y)

Hipotesis yang menyatakan terdapat pengaruh antara Kecerdasan Emosi dengan Kemampuan Mengajar Guru TK. Hal ini dapat diartikan bahwa makin tinggi Kecerdasan Emosi, maka semakin tinggi juga Kemampuan Mengajar Guru TK dan sebaliknya jika semakin rendah skor Kecerdasan Emosinya, maka semakin rendah juga Kemampuan Mengajar Guru TK. Secara statistik, hipotesis ini dapat dirumuskan sebagai berikut :

$$
\begin{aligned}
& \mathrm{H}_{0}=\rho \mathrm{y}_{\mathrm{i}}=0 \\
& \mathrm{H}_{1}=\rho \mathrm{y}_{1}>0
\end{aligned}
$$

Sebelum dilakukan uji korelasi, terlebih dahulu dilakukan uji regresi linier sederhana untuk mengetahui keberartian koefisien regresi $\mathrm{b}$ dan linieritas antara Kecerdasan Emosi (X1) dengan Kemampuan Mengajar Guru TK (Y). 
Berdasarkan perhitungan, diperoleh koefisien korelasi regresi b sebesar 0,29 dan nilai konstanta a sebesar 54,89 sehingga pengaruh antara Kecerdasan Emosi dengan Kemampuan Mengajar Guru TK dinyatakan dengan persamaan garis regresi $\hat{Y}=54,89+0,29 \mathrm{X}_{1}$.

Tabel 10. Anava Regresi Linier Sederhana Y atas $\mathrm{X}_{1}$ dengan Persamaan Regresi $\hat{\mathrm{Y}}=54,89+0,29 \mathrm{X}_{1}$.

\begin{tabular}{|c|r|r|r|c|c|c|}
\hline Model & $\begin{array}{r}\text { Sum of } \\
\text { Squares }\end{array}$ & df & $\begin{array}{c}\text { Mean } \\
\text { Square }\end{array}$ & F & F tabel & Sig. \\
\hline Regression & 449.648 & 1 & 449.648 & $\mathbf{6 . 1 7}$ & $\mathbf{4 , 0 2}$ & $\mathbf{. 0 1 9}^{\text {a }}$ \\
1 Residual & 3861.697 & 53 & 72.862 & & & \\
Total & 4311.345 & 54 & & & & \\
\hline
\end{tabular}

\begin{tabular}{|c|c|c|c|c|c|c|c|c|}
\hline & & & $\begin{array}{c}\text { Sum of } \\
\text { Squares }\end{array}$ & df & \begin{tabular}{c|} 
Mean \\
Square
\end{tabular} & $\mathbf{F}$ & \begin{tabular}{c|}
$\mathbf{F}$ \\
tabel
\end{tabular} & Sig. \\
\hline & & (Combined) & 2042.762 & 25 & 81.71 & 1.045 & & 0.452 \\
\hline & Between & Linearity & 449.648 & 1 & 449.65 & 5.748 & & $0 . c$ \\
\hline $\begin{array}{l}\text { Mengajar * } \\
\text { Kecerdasan }\end{array}$ & Groups & $\begin{array}{l}\text { Deviation } \\
\text { from }\end{array}$ & 1593.114 & 24 & 66.38 & 0.849 & 1,89 & 0.657 \\
\hline & & Linearity & & & & & & \\
\hline & Within G & roups & 2268.583 & 29 & 78.227 & & & \\
\hline & Total & & 4311.345 & 54 & & & & \\
\hline
\end{tabular}

Uji signifikansi dan linieritas persamaan regresi $\hat{\mathrm{Y}}=54,89+0,29 \mathrm{X}_{1}$. digunakan uji $\mathrm{F}$, kriteria uji signifikansi, jika $F_{\text {hitung }}$ lebih besar dari $F_{\text {tabel }}$ maka persamaan regresi tersebut dinyatakan signifikan sedangkan kriteria uji linieritas, jika $\mathrm{F}_{\text {hitung }}$ lebih kecil dari $\mathrm{F}_{\text {tabel }}$ maka persamaan garis regresi tersebut dinyatakan linier. Perhitungan uji signifikansi dan linieritas persamaan regresi $\hat{\mathrm{Y}}=54,89+0,29 \mathrm{X}_{1}$. dapat dilihat pada tabel 11 di atas.

Tabel 10 menunjukkan bahwa uji keberartian regresi menghasilkan $F_{\text {hitung }}=6,17$, sedangkan $\mathrm{F}_{\text {tabel }}$ dari daftar distribusi $\mathrm{F}$ dengan $\mathrm{dk}$ pembilang 1 dan $\mathrm{dk}$ penyebut 53 pada taraf signifikansi $\alpha=0,05$ diperoleh harga sebesar 4,02. Jadi $F_{\text {hitung }}$ lebih besar dari $F_{\text {tabel. }}$ Dengan demikian pengujian ini membuktikan bahwa arah regresi $\mathrm{Y}$ atas $\mathrm{X}_{1}$ adalah signifikan atau berarti.

Untuk uji linieritas, tabel 8 menunjukkan bahwa $F_{\text {hitung }}=0,85$, sedangkan $F_{\text {tabel }}$ dari daftar distribusi $\mathrm{F}$ dengan $\mathrm{dk}$ pembilang $24 \mathrm{dan} \mathrm{dk}$ penyebut 29 pada taraf signifikansi $\alpha=0,05$ diperoleh harga sebesar 1,89. Jadi $F_{\text {hitung }}$ lebih kecil dari $\mathrm{F}_{\text {tabel. }}$ Dengan demikian pengujian ini membuktikan bahwa bentuk regresi $\mathrm{Y}$ atas $\mathrm{X}_{1}$ adalah linier. Dengan pembuktian ini, maka tidak ada alasan untuk mencari model lain yang non linier bagi regresi $\mathrm{Y}$ atas $\mathrm{X}_{1}$.
Hal ini berarti bahwa apabila Kecerdasan Emosi ditingkatkan satu skor maka Kemampuan Mengajar Guru TK akan meningkat 0,29 pada konstanta 57,89. Setelah pengujian signifikansi dan linearitas persamaan regresi sebesar $\hat{Y}=54,89+0,29 X_{1}$ kemudian dilanjutkan perhitungan koefisien korelasi sederhana $\mathrm{X}_{1}$ dangan $\mathrm{Y}\left(\mathrm{ryx}_{1}\right)$ sebesar 0.05 . Signifikansi koefisien korelasi ry $\mathrm{x}_{1}$ melalui uji$\mathrm{t}$ dengan hasil yang diperoleh seperti dalam tabel 11.

Tabel 11. Hasil Perhitungan Korelasi $\mathrm{X}_{1}$ dengan Y

\begin{tabular}{|c|c|c|c|c|c|c|}
\hline \multirow{2}{*}{$\begin{array}{c}\text { Korelas } \\
\text { i }\end{array}$} & \multirow[b]{2}{*}{$\mathbf{n}$} & \multirow[b]{2}{*}{$\mathbf{r}$} & \multirow[b]{2}{*}{$\mathbf{r}^{2}$} & \multirow[b]{2}{*}{$\mathbf{t}_{\text {hit }}$} & \multicolumn{2}{|c|}{$\mathbf{t}_{\text {tab }}$} \\
\hline & & & & & $\begin{array}{c}0.0 \\
5\end{array}$ & $\begin{array}{c}0.0 \\
1\end{array}$ \\
\hline $\begin{array}{c}\mathrm{X}_{1} \\
\text { dengan } \\
\mathrm{Y}\end{array}$ & 55 & $\begin{array}{c}0,3 \\
2\end{array}$ & $\begin{array}{c}0,1 \\
0\end{array}$ & $\begin{array}{c}2,4 \\
8\end{array}$ & $\begin{array}{c}1,6 \\
7\end{array}$ & $\begin{array}{c}2,3 \\
9\end{array}$ \\
\hline
\end{tabular}

Pada tabel 11 di atas menunjukkan $t_{\text {hitung }}$ sebesar 2,48 lebih besar dari pada $t$ tabel 1,67, maka dapat disimpulkan bahwa $\mathrm{H}_{0}$ ditolak yang berarti terdapat pengaruh yang signifikan antara Kecerdasan Emosi dengan Kemampuan Mengajar Guru TK. Berdasarkan koefisien korelasi $\mathrm{r}_{\mathrm{yx} 1}$ tersebut di atas diperoleh koefisien determinasi 0.10 . Hal ini berarti bahwa $10 \%$ variasi Kemampuan Mengajar Guru TK dapat dijelaskan oleh Kecerdasan Emosi.

\section{Hubungan antara Konsep Diri $\left(\mathrm{X}_{2}\right)$ dengan Hasil Kemampuan Mengajar Guru TK (Y)}

Hipotesis yang menyatakan terdapat pengaruh antara Konsep Diri dengan Kemampuan Mengajar Guru TK. Hal ini dapat diartikan bahwa makin tinggi Konsep Diri, maka semakin tinggi juga Kemampuan Mengajar Guru TK dan sebaliknya jika semakin rendah Konsep Diri, maka makin rendah juga Kemampuan Mengajar Guru TK. Secara statistik, hipotesis ini dapat dirumuskan sebagai berikut;

$$
\begin{aligned}
& \mathrm{H}_{0}=\rho \mathrm{y}_{\mathrm{i}}=0 \\
& \mathrm{H}_{1}=\rho \mathrm{y}_{1}>0
\end{aligned}
$$

Sebelum dilakukan uji korelasi,terlebih dahulu dilakukan uji regresi linier sederhana untuk mengetahui keberartian koefisien regresi $b$ dan linieritas antara Konsep Diri $\left(\mathrm{X}_{2}\right)$ dengan Kemampuan Mengajar Guru TK(Y). Berdasarkan perhitungan, diperoleh koefisien korelasi regresi b sebesar 0,66 dan nilai konstanta a sebesar 30,69 sehingga pengaruh antara Konsep Diri dengan Kemampuan 
Mengajar Guru TK dinyatakan dengan persamaan garis regresi $\hat{Y}=30,69+0,66 \mathrm{X}_{2}$.

Uji signifikansi dan linieritas persamaan regresi $\hat{\mathrm{Y}}=30,69+0,66 \mathrm{X}_{2}$.digunakan analisis varians (anava) uji $\mathrm{F}$, kriteria uji signifikansi, jika $\mathrm{F}_{\text {hitung }}$ lebih besar dari $\mathrm{F}_{\text {tabel }}$ maka persamaan regresi tersebut dinyatakan signifikan sedangkan kriteria uji linieritas, jika $F_{\text {hitung }}$ lebih kecil dari $F_{\text {tabel }}$ maka persamaan garis regresi tersebut dinyatakan linier. Perhitungan uji signifikansi dan linieritas persamaan regresi $\hat{Y}=30,69+$ $0,66 \mathrm{X}_{2}$ dapat dilihat pada tabel 12 .

Tabel 12 menunjukkan bahwa uji keberartian regresi menghasilkan $F_{\text {hitung }} 15,80$ sedangkan $F_{\text {tabel }}$ dari daftar distribusi $\mathrm{F}$ dengan $\mathrm{dk}$ pembilang 1 dan $\mathrm{dk}$ penyebut 53 pada taraf signifikansi $\alpha=0,05$ diperoleh harga sebesar 4,02. Jadi $F_{\text {hitung }}$ lebih besar dari $F_{\text {tabel. }}$ Dengan demikian pengujian ini membuktikan bahwa arah regresi $\mathrm{Y}$ atas $\mathrm{X}_{2}$ adalah signifikan atau berarti.

Tabel 12. Anava Regresi Linier Sederhana $\mathrm{Y}$ atas $\mathrm{X}_{2}$ dengan Persamaan Regresi $\hat{\mathrm{Y}}=30,69+0,66 \mathrm{X}_{2}$

\begin{tabular}{|c|c|c|c|c|c|c|}
\hline Korelasi & $\mathbf{n}$ & $\mathbf{r}$ & $\mathbf{r}^{2}$ & $\mathbf{t}_{\text {hit }}$ & \multicolumn{2}{|c|}{$\mathbf{t}_{\text {tab }}$} \\
\hline $\begin{array}{c}\mathrm{X}_{2} \\
\text { dengan } \\
\mathrm{Y}\end{array}$ & 55 & 0,48 & 0.23 & 3,98 & 1,67 & 2,39 \\
\hline
\end{tabular}

\begin{tabular}{|c|c|c|c|c|c|c|c|c|}
\hline & $\begin{array}{l}\text { Sum of } \\
\text { Squares } \\
\end{array}$ & df & $\begin{array}{c}\text { Mean } \\
\text { Square }\end{array}$ & $\mathrm{F}$ & F tabel & Sig. \\
\hline \multirow{5}{*}{$\begin{array}{l}\text { Kemampua } \\
\text { n Mengajar } \\
\text { * Konsep } \\
\text { Diri }\end{array}$} & & (Combined) & 2251.645 & \multirow{5}{*}{$\begin{array}{l}2 \\
3 \\
3\end{array}$} & \multirow{5}{*}{$\begin{array}{r}102.348 \\
990.33 \\
60.063 \\
64.366\end{array}$} & \multirow{5}{*}{$\begin{array}{r}1.59 \\
15.386 \\
\mathbf{0 . 9 3 3}\end{array}$} & \multirow{5}{*}{1,89} & \multirow{5}{*}{$\begin{array}{r}0.113 \\
0 \\
0.557\end{array}$} \\
\hline & Between & Linearity & 990.33 & & & & & \\
\hline & & Deviation from & 1261.315 & & & & & \\
\hline & & Linearily & & & & & & \\
\hline & Total & & & & & & & \\
\hline
\end{tabular}

Untuk uji linieritas, tabel 12 menunjukkan bahwa $F_{\text {hitung }}=0,93$, sedangkan $F_{\text {tabel }}$ dari daftar distribusi $\mathrm{F}$ dengan $\mathrm{dk}$ pembilang $21 \mathrm{dan} \mathrm{dk}$ penyebut 32 pada taraf signifikansi $\alpha=0,05$ diperoleh harga sebesar 1,89. Jadi $F_{\text {hitung }}$ lebih kecil dari $\mathrm{F}_{\text {tabel. }}$ Dengan demikian pengujian ini membuktikan bahwa bentuk regresi $\mathrm{Y}$ atas $\mathrm{X}_{2}$ adalah linier. Dengan pembuktian ini, maka tidak ada alasan untuk mencari model lain yang non linier bagi regresi $\mathrm{Y}$ atas $\mathrm{X}_{2}$.

Setelah pengujian signifikansi dan linearitas persamaan regresi sebesar $\hat{Y}=30,69+0,66 X_{2}$ kemudian dilanjutkan perhitungan koefisien korelasi sederhana $\mathrm{X}_{2}$ dengan $\mathrm{Y}\left(\mathrm{ry}_{2}\right)$ sebesar 0,48 . Signifikansi koefisien korelasi ry ${ }_{2}$ melalui uji-t dengan hasil yang diperoleh seperti dalam tabel 13.

\begin{tabular}{|ll|r|r|r|r|r|r|}
\hline & Model & $\begin{array}{c}\text { Sum of } \\
\text { Squares }\end{array}$ & $\begin{array}{c}\text { Mean } \\
\text { df }\end{array}$ & $\begin{array}{c}\text { Squar } \\
\text { e }\end{array}$ & F & $\begin{array}{c}\text { F } \\
\text { tabel }\end{array}$ & Sig. \\
\hline $1 \quad$ Regression & 1014.632 & 2 & 507.31 & $\mathbf{8 . 0}$ & $\mathbf{4 . 0 2}$ & .001 \\
& & 6 & $\mathbf{0 2}$ & & \\
& Residual & 3296.714 & 5 & 63.398 & & & \\
& & 2 & & & & \\
& Total & 4311.345 & 5 & & & & \\
\hline
\end{tabular}

Tabel 13. Hasil Perhitungan Korelasi $\mathrm{X}_{2}$ dengan $\mathrm{Y}$

Pada tabel 13 di atas menunjukkan $t_{\text {hitung }}$ sebesar 3,98 lebih besar dari pada $t$ tabel 1,67, maka dapat disimpulkan bahwa $\mathrm{H}_{0}$ ditolak yang berarti terdapat pengaruh yang signifikan antara Konsep Diri dengan Kemampuan Mengajar Guru TK.

Berdasarkan koefisien korelasi $r_{\mathrm{y} 2}$ tersebut di atas diperoleh koefisien determinasi 0,23. Hal ini berarti bahwa 23\% variasi Kemampuan Mengajar Guru TKdapat dijelaskan oleh variasi Konsep Diri.

Hubungan antara Kecerdasan Emosi $\left(\mathbf{X}_{1}\right)$ dan Konsep Diri $\left(\mathrm{X}_{2}\right)$ dengan Kemampuan Mengajar Guru TK (Y)

Hipotesis yang menyatakan terdapat pengaruh antara Kecerdasan Emosi dan Konsep Diri dengan Kemampuan Mengajar Guru TK. Hal ini dapat diartikan bahwa makin tinggi Kecerdasan Emosi dan Konsep Diri, maka semakin tinggi juga Kemampuan Mengajar Guru TK dan sebaliknya jika rendah Kecerdasan Emosi dan Konsep Diri, maka semakin rendah juga Kemampuan Mengajar Guru TK. Secara statistik, hipotesis ini dapat dirumuskan sebagai berikut;

$$
\begin{aligned}
& \mathrm{H}_{0}=\rho \mathrm{y}_{\mathrm{i}}=0 \\
& \mathrm{H}_{1}=\rho \mathrm{y}_{1}>0
\end{aligned}
$$

Sebelum dilakukan uji korelasi ganda, terlebih dahulu dilakukan uji regresi linier sederhana untuk mengetahuan keberartian koefisien regresi b1, dan b2 yang terjadi secara bersamasama antara Kecerdasan Emosi $\left(\mathrm{X}_{1}\right)$ dan Konsep Diri $\left(\mathrm{X}_{2}\right)$ dengan Kemampuan Mengajar Guru TK (Y). Berdasarkan perhitungan, diperoleh koefisien korelasi regresi b1 sebesar 0,08, b2 
sebesar 0,59, dan nilai konstanta a sebesar 28,85

sehingga pengaruh antara Kecerdasan Emosi dan Konsep Diri dengan Kemampuan Mengajar Guru TK dinyatakan dengan persamaan garis regresi $\hat{Y}=28,85+0,08 X_{1}+0,59 X_{2}$.Pengujian signifikansi persamaan regresi ganda $\hat{Y}=28,85$ $+0,08 \mathrm{X}_{1}+0,59 \mathrm{X}_{2}$ digunakan analisis varians/ anava uji-F dengan (menggunakan SPSS 17), kriteria uji signifikansi, jika $F_{\text {hit }}$ lebih besar dari $F_{\text {tab }}$ maka persamaan regresi tersebut dinyatakan signifikan. Adapun perhitungan tersebut dapat dilihat pada tabel 14 .

Tabel 14 menunjukkan bahwa uji keberartian regresi menghasilkan $F_{\text {hitung }}=8,00$ sedangkan $F_{\text {tabel }}$ dari daftar distribusi $\mathrm{F}$ dengan $\mathrm{dk}$ pembilang 2 dan dk penyebut 52 pada taraf signifikansi $\alpha=0,05$ diperoleh harga sebesar 3,18. Jadi $F_{\text {hitung }}$ lebih besar dari $F_{\text {tabel. }}$ Dengan demikian pengujian ini membuktikan bahwa arah regresi Yatas $X_{1}, X_{2}$, adalah signifikan atau berarti. Ini berarti bahwa apabila bersamasama Kecerdasan $\operatorname{Emosi}\left(\mathrm{X}_{1}\right)$, dan konsep diri $\left(\mathrm{X}_{2}\right)$ ditingkatkan satu skor maka Kemampuan Mengajar Guru TK (Y) akan meningkat sebesar $0,08 \mathrm{X}_{1}+0,59 \mathrm{X}_{2}$ skor pada konstanta 28,85 .

Tabel 14. Anava Regresi Linier Sederhana Y atas

\begin{tabular}{|c|r|r|r|r|r|r|}
\hline Model & $\begin{array}{r}\text { Sum of } \\
\text { Squares }\end{array}$ & df & $\begin{array}{c}\text { Mean } \\
\text { Square }\end{array}$ & F & F tabel & Sig. \\
\hline Regression & 990.33 & 1 & 990.33 & $\mathbf{1 5 . 8 0 5}$ & $\mathbf{4 . 0 2}$ & $\mathbf{. 0 0 0}$ \\
1 Residual & 3321.02 & 53 & 62.661 & & & \\
Total & 4311.35 & 54 & & & & \\
\hline
\end{tabular}

Setelah pengujian signifikansi persamaan regresi selanjutnya dilakukan perhitungan korelasi ganda. Berdasarkan hasil perhitungan korelasi ganda diperoleh $\mathrm{r}_{\mathrm{y}, 12}=0.48$, untuk lebih jelasnya hasil perhitungan korelasi ganda dapat dilihat pada tabel 15 berikut ini

\begin{tabular}{|c|c|c|c|c|c|}
\hline $\begin{array}{l}\text { Tabel } 15 \\
\text { Korelasi }\end{array}$ & $\underset{\mathbf{n}}{\mathrm{Hasi}}$ & $\begin{array}{r}\text { Perhi } \\
r_{\mathrm{de}}\end{array}$ & $\begin{array}{l}\operatorname{agan} \\
\operatorname{an}^{\mathbf{r} Y}\end{array}$ & elas1 & $\underset{\mathbf{F}_{\text {tab }}}{\operatorname{dan}_{2}}$ \\
\hline 4 & 55 & 0,48 & 0,23 & 8,002 & 3,18 \\
\hline
\end{tabular}

Pada tabel 15 di atas menunjukkan $F_{\text {hit }}$ sebesar 8,00 lebih besar dari pada $\mathrm{F}$ tabel 3,18, maka dapat disimpulkan bahwa $\mathrm{H}_{0}$ ditolak yang berarti terdapat pengaruh yang signifikan antara Kecerdasan Emosi $\left(\mathrm{X}_{1}\right)$ dan Konsep Diri $\left(\mathrm{X}_{2}\right)$ dengan Kemampuan Mengajar Guru TK (Y).
Berdasarkan koefisien korelasi ganda $\mathrm{r}_{\mathrm{y} 12}$ tersebut di atas diperoleh koefisien determinasi $\left(r^{2}\right)$ sebesar 0,23. Dengan demikian hasil penelitian ini menyimpulkan bahwa terdapat pengaruh antara Kecerdasan Emosi dan Konsep Diri secara bersama-sama terhadap Kemampuan Mengajar Guru TK. Pengaruh antara variabel $\mathrm{X}_{1}$ dan $\mathrm{X}_{2}$ dengan variabel $\mathrm{Y}$ ini ditunjukan oleh koefisien korelasi ganda (r) sebesar 0,23. Kemudian dari koefisien determinasi $\left(\mathrm{r}^{2}\right)$ sebesar 0,23, ini berarti bahwa variasi variabel Kecerdasan Emosi dan Konsep Diri menjelaskan variasi Kemampuan Mengajar Guru TK sebesar 23\% dan sisanya atau residu sebesar $77 \%$ dijelaskan oleh variabel lain yang tidak dimasukkan dan diteliti dalam persamaan tersebut.

Setelah dilakukan pengujian koefisien korelasi ganda, kemudian dilanjutkan perhitungan korelasi parsial yaitu menguji koefisien dengan mengontrol variabel bebas, baik secara sendirisendiri maupun secara bersama. Untuk pengujian koefisien korelasi parsial $r_{y 1.2}$ dapat diketahui melalui pengujian korelasi parsial. Apabila dilakukan pengontrolan variabel adaptasi $\left(\mathrm{X}_{2}\right)$, diperoleh koefisien korelasi parsial $\mathrm{r}_{\mathrm{y} 1.2}$ sebesar 0.09 .

Untuk mengetahui signifikansi koefisien parsial $\mathrm{r}_{\mathrm{y} 1.2}$ tersebut dilanjutkan dengan uji-t. Adapun hasil perhitungan korelasi parsial dapat dilihat pada tabel 16 berikut ini.

Tabel 16. Hasil Perhitungan Korelasi Parsial $\mathrm{r}_{\mathrm{y} 1.2}$

\begin{tabular}{|c|c|c|c|c|}
\hline $\begin{array}{c}\text { Korelasi } \\
\text { Parsial }\end{array}$ & $\mathbf{n}$ & $\mathbf{r}$ & $\mathbf{t}_{\text {hit }}$ & $\mathbf{t}_{\text {tab }}$ \\
\hline $\mathbf{r}_{\mathrm{y} 1.2}$ & 55 & 0.09 & 0,62 & 1,67 \\
\hline
\end{tabular}

Pada tabel 16 di atas menunjukkan $t_{\text {hitung }} 0,62$ lebih kecil dari pada $t_{\text {tabel }}$ sebesar 1,67 sehingga dapat disimpulkan bahwa koefisien korelasi parsial $r_{y 1.2}$ sebesar 0,09 adalah tidak signifikan, yang berarti bahwa tidak terdapat pengaruh antara Kecerdasan Emosi dengan Kemampuan Mengajar Guru TK dengan variabel adaptasi (Konsep Diri) dikontrol.

Apabila dilakukan pengontrolan variabel adaptasi $\left(\mathrm{X}_{1}\right)$, diperoleh koefisien korelasi parsial $r_{\mathrm{y} 2.1}$ sebesar 0,38, Untuk mengetahui signifikansi koefisien parsial $r_{\mathrm{y} 2.1}$ tersebut dilanjutkan dengan uji - t. Adapun hasil 
perhitungan korelasi parsial dapat dilihat pada tabel 16 berikut ini.

Tabel 17. Hasil Perhitungan Korelasi Parsial $\mathrm{r}_{\mathrm{y} 2.1}$

\begin{tabular}{|c|c|c|c|c|}
\hline $\begin{array}{c}\text { Korelasi } \\
\text { Parsial }\end{array}$ & $\mathbf{N}$ & $\mathbf{r}$ & $\mathbf{t}_{\text {hit }}$ & $\mathbf{t}_{\text {tab }}$ \\
\hline $\mathrm{r}_{\mathrm{y} 2.1}$ & 30 & 0,38 & 2,98 & 1,67 \\
\hline
\end{tabular}

Pada tabel 17 di atas menunjukkan thitung 2,98 lebih besar dari pada $t_{\text {tabel }}$ sebesar 1,67 sehingga dapat disimpulkan bahwa koefisien korelasi parsial $r_{y 2.1}$ sebesar 0,38 adalah signifikan yang berarti bahwa terdapat pengaruh antara Konsep Diri dengan Kemampuan Mengajar Guru TK, meskipun variabel adaptasi (Kecerdasan Emosi) dikontrol.

\section{Pembahasan Hasil Penelitian}

Berdasarkan hasil pengujian hipotesis, ternyata ketiga hipotesis yang diajukan menunjukkan hasil yang berkorelasi secara signifikan. Uraian masing-masing hipotesis tersebut dapat dijelaskan sebagai berikut:

\section{Hubungan antara Kecerdasan Emosi dengan Kemampuan Mengajar Guru TK}

Hasil perhitungan tentang hipotesis yang menyebutkan bahwa terdapat pengaruh yang signifikan antara Kecerdasan Emosi $\left(\mathrm{X}_{1}\right)$ dengan Kemampuan Mengajar Guru TK (Y) menunjukkan model persamaan regresi sederhana $\hat{Y}=54,89+0,29 \mathrm{X}_{1}$. Melalui analisis varians untuk signifikansi diperoleh $\mathrm{F}_{\text {hitung }}=$ 6,17 lebih besar $F_{t}=4,02$ sedangkan untuk linieritas diperoleh $\mathrm{F}_{\text {hitung }}=0$,85lebih kecil $\mathrm{F}_{\text {tabel }}$ $=1,89$ sehingga persamaan regresi sederhana yaitu $\hat{\mathrm{Y}}=54,89+0,29 \mathrm{X}_{1}$ dinyatakan signifikan dan linier. Artinya apabila Kecerdasan Emosi ditingkatkan satu skor maka Kemampuan Mengajar Guru TK akan meningkat 0,29 pada konstanta 54,89 .

Selanjutnya koefisien korelasi antara Kecerdasan Emosi $\left(\mathrm{X}_{1}\right)$ dengan Kemampuan Mengajar Guru TK (Y) sebesar 0,32. Melalui uji-t diperoleh $t_{\text {hitung }}$ sebesar 2,48 lebih besar dari pada $t_{\text {tabel }}$ sebesar 1,67 sehingga koefisien korelasi $\left(\mathrm{r}_{\mathrm{y} 1}\right)$ dinyatakan signifikan pada taraf signifikansi 0.05 yang berarti bahwa makin tinggi Kecerdasan Emosi maka semakin tinggi Kemampuan Mengajar Guru TK. Sebaliknya, apabila Kecerdasan Emosi semakin rendah akan membawa konsekwensi rendahnya Kemampuan Mengajar Guru TK. Berdasarkan koefisien korelasi $\left(r_{\mathrm{y} 1}\right)$ tersebut juga diperoleh nilai determinasi 0,10 , hal ini berarti bahwa variasi Kemampuan Mengajar Guru TK dapat dijelaskan oleh variasi Kecerdasan Emosi sebesar $10 \%$ dan sisanya atau residu sebesar 90\% dijelaskan oleh variabel lain.

Temuan dalam penelitian ini sejalan dengan kajian teoritis yang dikemukakan pada bab II terdahulu bahwa Guru TK yang memiliki Kecerdasan Emosi yang baik akan memiliki Kemampuan Mengajar Guru TK dengan optimal. Dengan demikian dapat dikatakan bahwa Kemampuan Mengajar Guru TK terkait dengan Kecerdasan Emosi yang dimiliki oleh Guru TKyang bersangkutan. Disamping itu, hasil penelitian ini juga menunjukkan bahwa Kecerdasan Emosi penting dimiliki dan ditingkatkan oleh setiap Guru TK di Larangan Tangeranguntuk meningkatkan Kemampuan Mengajar Guru TK.

Jika dilihat secara parsial pengaruh Kecerdasan Emosi dengan Kemampuan Mengajar Guru TK dengan mengontrol variabel Konsep Diri diperoleh koefisien korelasi parsial $\left(\mathrm{r}_{\mathrm{y} 1.2}\right)$ sebesar 0.09. Ini berarti bahwa keterkaitan tersebut telah membatasi keterlibatan pengaruh terhadap variabel bebas lainnya. Selanjutnya pengontrolan variabel tersebut memperlihatkan penurunan keeratan pengaruh antara Kecerdasan Emosi dengan Kemampuan Mengajar Guru TK, tetapi koefisien korelasi parsial tersebut tidak signifikan. Hal ini karena $\mathrm{t}_{\text {hit }}(0,62) \geq \mathrm{t}_{\text {tab }}(1,67)$.

\section{Hubungan antara Konsep Diri dengan Kemampuan Mengajar Guru TK}

Hasil perhitungan tentang hipotesis yang menyebutkan bahwa terdapat pengaruh yang signifikan antara Konsep Diri $\left(\mathrm{X}_{2}\right)$ dengan Kemampuan Mengajar Guru TK (Y) menunjukkan model persamaan regresi sederhana $\hat{Y}=30,69+0,66 \mathrm{X}_{2}$. Melalui analisis varians untuk signifikansi diperoleh $\mathrm{F}_{\text {hitung }}=15,80$ lebih besar $\mathrm{F}_{\text {tabel }}=4,02$ sedangkan untuk linieritas diperoleh $\mathrm{F}_{\mathrm{h}}=0,93$ lebih kecil $\mathrm{F}_{\mathrm{t}}=1,89$ sehingga persamaan regresi sederhana yaitu $\hat{Y}=30,69+0,66 X_{2}$ dinyatakan signifikan dan linier. Artinya apabila Konsep Diri ditingkatkan satu skor maka Kemampuan Mengajar Guru TK akan meningkat 0,66 pada konstanta 30,69 . 
Selanjutnya koefisien korelasi antara Konsep Diri $\mathrm{X}_{2}$ dengan Kemampuan Mengajar Guru TK sebesar 0.48. Melalui uji-t diperoleh $t_{\text {hitung }}$ sebesar 3,98 lebih besar dari pada $t_{\text {tabel }}$ sebesar 1,67 sehingga koefisien korelasi $\left(\mathrm{r}_{\mathrm{y} 2}\right)$ dinyatakan signifikan pada taraf 0.05 yang berarti bahwa semakin tinggi Konsep Diri maka semakin tinggi Kemampuan Mengajar Guru TK. Sebaliknya, apabila Konsep Diri rendah akan membawa konsekwensi rendahnya Kemampuan Mengajar Guru TK. Berdasarkan koefisien korelasi $\left(\mathrm{r}_{\mathrm{y} 2}\right)$ tersebut juga diperoleh nilai determinasi 0,23 , hal ini berarti bahwa variasi Kemampuan Mengajar Guru TK dapat dijelaskan oleh variasi Konsep Diri sebesar $23 \%$ dan sisanya atau residu sebesar $77 \%$ dijelaskan oleh variabel lain.

Temuan dalam penelitian ini sejalan dengan kajian teoritis yang dikemukakan terdahulu bahwa Guru TK di Larangan- Tangerang yang memiliki Konsep Diri yang tinggi/ baik akan mampu mengajar dengan baik dan optimal. Dengan demikian dapat dikatakan bahwa Kemampuan Mengajar Guru TK terkait dengan Konsep Diri yang dimiliki para guru. Disamping itu, hasil penelitian ini juga menunjukkan bahwa Konsep Diri penting dimiliki dan ditingkatkan oleh setiap Guru TK dalam meningkatkan kemampuan mengajar mereka.

Jika dilihat secara parsial pengaruh Konsep Diri dengan Kemampuan Mengajar Guru TK dengan mengontrol variabel Kecerdasan Emosi diperoleh koefisien korelasi parsial $\left(\mathrm{r}_{\mathrm{y} 2.1}\right)$ sebesar 0.38, ini berarti bahwa keterkaitan tersebut telah membatasi keterlibatan pengaruh terhadap variabel bebas lainnya. Selanjutnya pengontrolan variabel tersebut memperlihatkan penurunan keeratan pengaruh antara Konsep Diri dengan Kemampuan Mengajar Guru TK, tetapi koefisien korelasi parsial tersebut tetap signifikan. Hal ini karena $t_{\text {hitung }}(2,98) \geq t_{\text {tabel }}$ $(1,67)$.

\section{Hubungan antara Kecerdasan Emosi dan Konsep Diri dengan Kemampuan Mengajar Guru TK}

Hasil penelitian tentang hipotesis yang menyebutkan bahwa terdapat pengaruh antara Kecerdasan Emosi dan Konsep Diri dengan hasil Kemampuan Mengajar Guru TK menunjukkan model persamaan regresi ganda $\hat{\mathrm{Y}}=28,85+0,08 \mathrm{X}_{1}+0,59 \mathrm{X}_{2}$. Melalui analisis varians untuk signifikansi diperoleh $F_{\text {hitung }}$ sebesar 8,00 lebih besar dari pada $\mathrm{F}_{\text {tabel }}$ 4,02 dan memiliki kategori signifikan $\left(\operatorname{sig} 0,001^{\mathrm{a}}\right)$, sehingga dengan demikian persamaan ganda yaitu $\hat{Y}=28,85+0,08 X_{1}+0,59 X_{2}$ dinyatakan signifikan. Artinya, apabila secara bersamasama Kecerdasan Emosi dan Konsep Diri ditingkatkan satu skor maka hasil Kemampuan Mengajar Guru TK meningkat sebesar $0,08 \mathrm{X}_{1}$ $+0,59 \mathrm{X}_{2}$ skor pada konstanta 28,85. Berdasarkan persamaan regresi ganda di atas menunjukkan bahwa diantara kedua variabel bebas tersebut yang paling tinggi memberikan peningkatan Kemampuan Mengajar Guru TK apabila ketiga variabel bebas dinaikkan satu unit adalah variabel Konsep Diri $\left(0,59 \mathrm{X}_{2}\right)$ dan yang kedua Kecerdasan Emosi $\left(0,08 \mathrm{X}_{1}\right)$.

Selanjutnya koefisien korelasi ganda secara bersama-sama antara Kecerdasan Emosi dan Konsep Diri dengan Kemampuan Mengajar Guru TK diperoleh $\left(\mathrm{R}_{\mathrm{y} 12}\right)$ sebesar 0.48 . Pengujian signifikansi melalui uji $\mathrm{F}$ diperoleh $F_{\text {hitung }}$ sebesar 8,00 lebih besar dari pada $F_{\text {tabel }}$ sebesar 3,18 dan dinyatakan signifikan dengan signifikansi $0,001^{\mathrm{a}}$ sehingga koefisien korelasi ganda $\left(\mathrm{R}_{\mathrm{y} 12}\right)$ dinyatakan signifikan yang berarti bahwa semakin tinggi Kecerdasan Emosi, dan Konsep Diri secara bersama-sama semakin tinggi juga Kemampuan Mengajar Guru TK. Sebaliknya, makin rendahnya Kecerdasan Emosi dan Konsep Diri semakin rendah juga Kemampuan Mengajar Guru TK di Larangan Tangerang.

Berdasarkan koefisien korelasi ganda $\left(\mathrm{R}_{\mathrm{y} 12}\right)$ tersebut, akan diperoleh koefisien determinasi sebesar 0,23 sehingga dengan demikian temuan dalam penelitian ini menunjukkan pentingnya variabel Kecerdasan Emosi dan Konsep Diri untuk meningkatkan Kemampuan Mengajar Guru TK, oleh karena secara bersama-sama kedua variabel tersebut menjelaskan variasi Kemampuan Mengajar Guru TK sebesar $23 \%$. Hal ini sejalan dengan teori masing-masing variabel bebas yang telah dijelaskan pada bagian sebelumnya.

Secara keseluruhan dapat disimpulkan bahwa setelah dilakukan pengujian secara statistik terhadap data empirik yang telah diperoleh dari lapangan dapat dikatakan bahwa kedua variabel bebas yang diajukan yaitu Kecerdasan Emosi dan Konsep Diri berkorelasi secara signifikan 
dengan Kemampuan Mengajar Guru TK di Larangan - Tangerang.

\section{KESIMPULAN DAN SARAN}

\section{Kesimpulan}

Berdasarkan hasil penelitian yang telah diuraikan di atas, maka dapat diambil suatu kesimpulan sebagai berikut:

1. Berdasarkan hasil pengujian hipotesis pertama menunjukan bahwa terdapat hubungan yang signifikan antara Kecerdasan Emosi $\left(\mathrm{X}_{1}\right)$ dengan Kemampuan Mengajar Guru TK (Y) yang menunjukkan apabila kecerdasan emosi ditingkatkan maka kemampuan mengajar guru Tk juga akan meningkat. Untuk itu seorang guru harus dapat mengolah emosinya dan mengontrol emosinya. Karena pada hakikatnya seorang guru adalah pribadi yang multiperan, sebagai ibu (bagi anak-anaknya), istri (bagi yang sudah menikah), guru dan sebagai pribadi bagi dirinya.

2. Berdasarkan hasil pengujian hipotesis kedua menunjukan bahwa terdapat hubungan yang signifikan antara Konsep Diri $\left(\mathrm{X}_{2}\right)$ dengan Kemampuan Mengajar Guru TK (Y) apabila konsep diri ditingkatkan maka kemampuan mengajar seorang guru juga akan meningkat. Dimana konsep diri seorang guru adalah bagaimana seorang guru itu dapat memahami dirinya sebagai guru yang baik. Guru yang memiliki konsep diri yang baik harus dapat mentransfer pengetahuan, keterampilan, perilaku, bahasa kepada anak didiknya. Sehingga seorang anak didik dapat meniru segala perbuatan yang dilakukan gurunya. Seperti kita ketahui bahwa guru itu digugu dan ditiru.

3. Hasil penelitian tentang hipotesis yang menyebutkan bahwa terdapat pengaruh antara Kecerdasan Emosi dan Konsep Diri terhadap Kemampuan Mengajar Guru TK maka apabila kecerdasan emosi dan konsep diri ditingkatkan maka kemampuan mengajar guru TK juga akan meningkat. Untuk itu agar kemampuan mengajar di TK meningkat maka seorang guru harus dapat mengolah dan mengontrol emosinya. Selain itu seorang guru juga harus memahami akan dirinya sebagai seorang pendidik yang memiliki tanggung jawab moril kepada peserta didik. Sehingga apabila kecerdasan emosi dan konsep diri ditingkatkan,maka kemampuan mengajar guru TK juga akan meningkat.

\section{Saran}

Berdasarkan uraian pada kesimpulan dan implikasi penelitian, berikut akan dikemukakan beberapa saran untuk meningkatkan Kemampuan Mengajar Guru TK sebagai berikut:

1. Untuk mengoptimalkan Kemampuan Mengajar Guru TK selain menguasai metode mengajar juga harus memiliki Kecerdasan Emosi dan Konsep Diri yang baik. Karena apapun keberadaan Kecerdasan Emosi dan Konsep Diri ini tetap memiliki hubungan yang sangat erat dengan Kemampuan Mengajar Guru TK. Sehingga untuk mendapatkan Kemampuan Mengajar Guru TK yang baik, selain meningkatkan metode mengajar juga perlu ditingkatkan Kecerdasan Emosi dan Konsep Diri dalam dirinya.

2. Sebagai bahan masukan bagi guru dan pengurus TK agar selalu memperhatikan unsur-unsur pendukung seperti Kecerdasan Emosi, dan Konsep Diri dalam proses pembelajaran untuk mendapatkan Kemampuan Mengajar Guru TK yang baik. Selain itu guru juga harus mengikuti pelatihan, workshop dan seminar-seminar yang tujuannya untuk meningkatkan kemampuan mengajar guru TK. Studi banding ke sekolah-sekolah juga merupakan salah satu cara untuk meningkatkan kemampuan mengajar. Dengan cara seperti ini diharapkan guru dapat mengajar dengan baik.

3. Bagi pengurus yayasan (sekolah) TK, jika masih ditemui adanya guru yang memiliki Kecerdasan Emosi dan Konsep Diri yang rendah, hendaknya segera diantisipasi dengan melakukan perbaikan kwalitas dengan pelatihan dan memberikan motivasi.

4. Karena penelitian sifatnya terbatas maka disarankan bagi peneliti lainnya agar dilakukan penelitian lain dan mengembangkannya atau meneliti dengan variabel-variabel lainnya yang berhubungan dengan Kemampuan Mengajar Guru TK. 


\section{DAFTAR PUSTAKA}

[1] Amstrong, Thomas. You're Smarter Than You Think: Катu Itu Lebih Cerdas daripada yang kamu Duga, Arvin Saputra Batam: Interaksa,2004

[2] Arikunto, Suharsimi.Prosedur Penelitian, Rineka Cipta:1997

[3] Bahaudin, Taufik. Brainware Management. Jakarta : PT. Alex Media Komputindo, 2003

[4] Cherrington, D.J,Organizational Behavir: The Management of Individual and Organizational Performance. Massachusetts: Allyn and Baco,

[5] Faizah, Dewi Utama, Keindahan Belajar Dalam Perspektif Pedagogi, Jakarta: Cindy Grafika, 2008.

[6] Gardner, Howard. Multiple Intelligence After 20 Years, Paper Presented at The American Educational Research Assosiation, 2003

[7] Goleman, Daniel. Emotional Intelegence. Jakarta : PT. Gramedia Pustaka Utama, 1998

[8] Hendriati, Psikologi Perkembangan. Bandung : Refika Aditama, 2006

[9] Hoerr, Thomas R. Buku Kerja Multiple Intelligence. Bandung : Penerbit Kaifa, 2007

[10] Jamaris, Martini. Perkembangan dan Pengembangan Anak Usia Taman KanakKanak. Jakarta : Grasindo, 2006

[11] Mappiare A, Psikologi Remaja. Surabaya: Usaha Nasional, 1992

[12] Muhibbin Syah. Psikologi Pendidikan. Bandung: PT Remaja Rosdakarya.1999
[13] Mulyasa. Menjadi Guru Profesional, Bnadung:PT Rosda Karya:2007

[14] Muwarni,Santosa.Statistika Terapan, UHAMKA:2000

[15] Nana Syaodih. Landasan Psikologi Proses Pendidikan, Bandung: PT Remaja Rosdakarya. 2003

[16] Robbins. Stephen. P 1996, Perilaku Organisasi, Edisi Bahasa Indonesia, Jilid I. PT. Prenlindo, Jakarta. 1996

[17] Rivai, Veitzal. Kiat Memimpin Dalam Abad ke -21, Jakarta, PT Raja Grafindo Persada, 2003

[18] Rustiyah, M.K. Kompetensi Mengajar dan Guru, Jakarta:1999

[19] Satia Darma, Monty. Mendidik Kecerdasan. Jakarta : Pustaka Populer Obor,2003

[20] Sanjaya, Wina. Strategi Pembelajaran Berorientasi Standar Proses Pendidikan, Jakarta: Kencana, 2008

[21] Singaribun, Masri.Metodologi Penelitian Survey, Jakarta:1999

[22] Sugiono. Metode Penelitian Pendidikan. Bandung: Penerbit Alphabet, 2007

[23] Sudjana, Metode Statistik. Bandung: 1996

[24] Suryabrata,Sumadi. Psikologi Pendidikan, Jakarta : CV Rajawali, 1995

[25] Suparno. Manajemen Kepribadian, Jakarta: Pilar Multisindo.2005

[26] Usman, Moh. Uzer. Menjadi Guru Profesional. Bandung: Remaja Rosdakarya. 1996

[27] Victor, Kiam. Enterpreneural Quetiont, 1999

[28] Weisinger, Hendrie. Emotional Intelligence at work. Yosey. Bas Inc Publisher. $1^{\text {st }}$ ed., 1998 